\title{
Risk, Financial Stability and FDI
}

\author{
Neil M. Kellard*, Alexandros Kontonikas*, Michael J. Lamla ${ }^{\dagger}$, Stefano Maiani*1 and Geoffrey \\ $\mathrm{Wood}^{++}$ \\ *Essex Business School, University of Essex, United Kingdom \\ ${ }^{\dagger}$ Leuphana University Lüneburg, Germany, and KOF Swiss Economic Institute, ETH Zurich \\ ${ }^{+\dagger}$ Western University, Canada
}

\begin{abstract}
All Foreign Direct Investment (FDI) involves risk. Augmenting the international finance literature, we assess the effects of financial system risk on FDI trends through considering both origin and host country effects. Motivated by the sovereign debt crisis and based on a dataset including bilateral FDI holdings, this paper investigates the implications of sovereign and bank-related risk on FDI in the Eurozone. Strikingly, we find that in terms of banking risk, it is only that encountered in the country of origin that has an impact on FDI choices. However, we find that sovereign risk, in both origin and host countries, have effects. As a corollary, we suggest that although poor financial discipline by host governments has been widely blamed as the primary factor likely to frighten off overseas investors, it is amongst FDI supplying nations that the effects of sovereign yields seem most pronounced. Policymakers in countries seeking to attract FDI should not only be attentive to domestic conditions, but also be aware of the financing environment that multinational enterprises (MNEs) encounter in their home countries and how this might impact on their choices.
\end{abstract}

Keywords: Foreign Direct Investment; Financial Stability; Sovereign Yields; Euro Area; International Regulation.

JEL Classification: F21, F23, F30, F36.

\footnotetext{
${ }^{1}$ Corresponding author: Essex Business School, University of Essex, Wivenhoe Park, Colchester, CO4 3SQ, Essex, United Kingdom. E-mail: s.maiani@essex.ac.uk.

* Essex Business School, University of Essex, Wivenhoe Park, Colchester, CO4 3SQ, Essex, United Kingdom. E-mails: nkellard@essex.ac.uk (Neil M. Kellard), a.kontonikas@essex.ac.uk (Alexandros Kontonikas).

$\dagger$ First affiliation: Leuphana University Lüneburg, Universitätsallee 1, 21335 Lüneburg, Germany.

Second affiliation: KOF Swiss Economic Institute, ETH Zurich, Rämistrasse 101, 8092 Zürich, Switzerland.

E-mail: lamla@leuphana.de

${ }^{\dagger \dagger}$ Western University, 1151 Richmond St, London, ON N6A 3K7, Canada. E-mail: gwood23@uwo.ca

We would like to thank Cecilio Tamarit, for his insightful discussion of our paper, Jakob de Haan, Jacopo Cimadomo, Davide Romelli, Davide Furceri as well as the participants of the 'The Euro Area at 20: Evaluating the Real Side of the Economic and Monetary Union' conference for helpful suggestions and comments. We are indebted to the very helpful input, advice and guidance of the anonymous referees. Declaration of interest: none.
} 


\section{Introduction}

Over the past decade, Foreign Direct Investment (FDI) stock has grown markedly, rising almost $65 \%$ at a global level. This led to an increasing awareness on behalf of policymakers as to its role as a source of economic growth. For example, in 2016, FDI accounted for 35\% of global GDP (Carril-Caccia \& Pavlova, 2018; Neto \& Veiga, 2013). The Euro Area (EA) has been both a key recipient of FDI investments and an important FDI supplier. This has been attributed not only to the elimination of transaction costs and exchange risk in the reallocation of capital between members of the monetary union (Lane \& Milesi-Ferretti, 2008; Darvas et al., 2013), but also to an increase in international investors' confidence in its financial institutions and supervisory bodies (Shatz \& Venables, 2000). In the aftermath of the Global Financial Crisis (GFC), worries about fiscal sustainability in the EA intensified (Merler and Pisani-Ferry, 2012; Arghyrou \& Kontonikas, 2012; Bernoth \& Erdogan, 2012; Afonso et al., 2014, 2018) as risks in the banking sector fed back to the sovereign position and vice versa, generating a detrimental cycle (De Bruyckere et al., 2013; Acharya et al., 2014; Delatte et al., 2017). As a result, in the run-up of the sovereign debt crisis, the EA experienced significant capital outflows.

In this context, our paper examines how sovereign and banking sector risks that accumulated during the crises affected FDI in the EA. More specifically, we dissect the effect of sovereign and banking risk in origin (foreign investors) and host countries (EA), which we consider as main drivers of investors' capital allocation in the period of analysis. We draw from several strands of the literature on FDI in scenarios of crisis (e.g., Milesi-Ferretti \& Tille, 2010; Weitzel et al., 2014; Darvas et al., 2013; Habib and Venditti, 2018; Acharya et al., 2007; CarrilCaccia \& Pavlova, 2018; Sondermann \& Vansteenkiste, 2019), as well as work on investment allocation during the sovereign debt crisis (e.g., Beck et al., 2016; Weitzel et al., 2014). However, our approach extends the empirical literature on FDI that typically considers just domestic factors as drivers for foreign investment (e.g., Carril-Caccia \& Pavlova, 2018; Dellis 
et al., 2016; Razin \& Sadka, 2007). By contraposing banking and sovereign stress in the country where FDI originates (i.e., the origin country) with the corresponding recipient country of FDI (i.e., the host), our paper isolates the impact that EA countries' sovereign and banking risk have on their ability to attract FDI from other factors, whilst also considering the relative importance of origin countries' domestic risk. Moreover, we provide evidence on cross-country spillovers arising from sovereign and banking sectors' stress and the transmission to the Euro Area through FDI. From a methodological perspective, we argue that the modelling of the EA constitutes per se an ideal setting for our empirical analysis, given all countries in the European Monetary Union (EMU) have a common currency and monetary policy, which mutes the effect from monetary transmission and allows for a cleaner identification of variations in the financial account of the Balance of Payments.

The empirical analysis employs a large panel dataset from the IMF Coordinated Foreign Direct Investment Survey (IMF CDIS) on 112 countries FDI stock positions between 2009 and 2016, which we adopt to identify inward FDI in the EA. The main advantage of this dataset is that disaggregating countries' FDI positions using their immediate counterpart, the CDIS data allows for a cross-country and over time comparison of FDI positions (Damgaard \& Elkjaer, 2017). We subsequently match the obtained data on bilateral FDI positions with bank and sovereign risk measures for host and origin countries. Additionally, we control for all the standard gravity variables commonly used in extant literature on international FDI (e.g., Martin \& Rey, 2004; Portes \& Rey, 2005; Daude \& Fratzscher, 2008).

Our empirical work yields three main findings. Firstly, we observe that an increase in non-performing loans-over-total loans - widely employed in the banking literature (see Aiyar \& Monaghan, 2015) to test banking sector stability - in the origin country leads to a decrease in FDI. However, importantly, changes in the corresponding bank risk in host countries leaves inward-FDI unaffected. Secondly, we find that FDI responds negatively to upturns in sovereign 
yields both in origin as well as host countries, arguing that (i) an increase in origin country sovereign yield encourages corporate sector Multinational Enterprises (MNEs) to engage in less risk-taking, whilst (ii) an increase in host country yield implies that other destinations appear more attractive. Additionally, when the EA sample is separated into subsamples of nonstressed and stressed (GIIPS: Greece, Ireland, Italy, Portugal and Spain) countries, these findings are confirmed, reinforcing our confidence regarding the identified transmission channels. In a nutshell, what we find is that economic conditions - including financial stability - in origin countries particularly matters for FDI. Here, the key point is the identification of a spillover effect of risk in origin countries to the Euro Area through FDI. Finally, we re-affirm findings in the literature related to the importance of economic and financial ties in investment and financing decisions, embedded in standard gravity variables.

Overall, we identify four main strands of the FDI literature to which our work relates. Firstly, there is a wide range of literature affirming the importance of economic and financial ties in investment and financing decisions, embedded in standard gravity models. These results find a common root in both the literature on institutional affinity (see Shukla \& Cantwell, 2018), or on transaction costs, whereby ceteris paribus, countries' geographical closeness or common cultural background considerably reduces informational and transaction costs, therefore affecting FDI decisions (Martin \& Rey, 2004; Portes \& Rey, 2005; Daude \& Fratzscher, 2008; Beck et al., 2016; Lane \& Milesi-Ferretti, 2008; Sondermann \& Vansteenkiste, 2019). Other factors similarly popular in this literature consist of proxies for institutional quality (see Dellis et al., 2017), as well as identifiers of incentives for regulatory or tax evasion (see Damgaard et al., 2018; Haufler et al., 2018; Egger et al., 2018). In our paper, we include standard gravity variables adopted by the previous literature, as well as additional variables which are specific to the context of crisis under consideration. Secondly, we draw from a limited number of studies that consider the response of FDI to macroeconomic shocks 
arising during crises. These include studies on the Asian financial crisis (Aguiar and Gopinath, 2005; Acharya et al., 2007), the Latin American financial crisis (Krugman, 2000), other emerging markets crises (Alquist et al., 2013), and the GFC and sovereign debt crisis (Demertzis \& Pontuch, 2013; Forster et al., 2011; Darvas et al., 2013; Beck et al., 2016; Sondermann \& Vansteenkiste, 2019). Thirdly, we contribute to studies on the sovereign debt crisis and determinants of euro-area sovereign bond yield spreads (vs. German bunds), which are commonly viewed as key indicators of crisis intensity (Arghyrou \& Kontonikas, 2012; Bernoth \& Erdogan, 2012; Afonso et al., 2014, 2018). Such studies investigate the role of banking risk in transforming the GFC into sovereign debt crisis, and consequently, the nexus between banking risk and sovereign risk (De Bruyckere et al., 2013; Acharya et al., 2018; Delatte et al., 2017). Finally, a set of studies on FDI considers the EMU membership and its impact on the ability of its composing countries to attract FDI (see Shatz \& Venables, 2000; Carril-Caccia \& Pavlova, 2018; Sondermann \& Vansteenkiste, 2019).

The rest of the paper is structured as follows: in Section 2 we further explore the theoretical and empirical background that motivates our study. In Section 3, we explain the proposed methodology. In Section 4, we provide an exhaustive description of our dataset and the underlying literature justifying our choices. The empirical results are presented in Section 5. In Section 6, we present robustness tests and, in Section 7, the conclusions.

\section{Theoretical and empirical background}

The recent crises experienced by countries in the Euro Area, as well as the GFC, provided nontrivial evidence on the effect of bank credit cycles on economic growth, and fiscal and financial stability (Shin, 2012; Rey, 2013; Habib \& Venditti, 2018). The build-up (and subsequent decline) of bank credit growth has been detrimental for domestic economies and a crucial predictor of crisis, and also largely synchronised on a global scale (Shin, 2012; Rey, 2013; 
Banti \& Phylaktis, 2019). Similarly, in the context of the sovereign debt crisis, sovereign yields increased in numerous countries and regions. Several authors found evidence of contagion arising from spillovers from stressed EA countries sovereign risk across the EA (see Claeys \& Vašícek, 2014) and other advanced and emerging economies (Beirne \& Fratzscher, 2013).

In light of the above evidence, it becomes interesting to distinguish between origin and host countries' financial conditions when analysing the determination of inward FDI in the Euro Area. To do so, our paper newly hypothesises that both host and origin countries' conditions are relevant determinants of cross-country transmission of global FDI. In particular, we posit that greater risk in the origin country's banking sector (observed using the outstanding amount of non-performing loans as a ratio of total bank loans) is expected to depress FDI in the EA. This can be interpreted as a 'leverage channel', whereby firms borrow from banks in their home country to finance investment, including FDI. This effect will be stronger for firms wishing to invest overseas where imperfect knowledge considerations are greater. According to this argument, credit availability ${ }^{1}$ is an important determinant of FDI. The importance of credit cycles for the real economy (Bernanke \& Gertler, 1990; Bordo \& Jeanne, 2002; Chen et al., 2012) has led to attempts by policymakers to tame them. Similarly, we assume that in origin countries, greater sovereign credit risk (observed by examining the yields of 10-year national government bonds) will encourages the corporate sector MNEs to engage in less risk-taking. This is due to a stronger motive for companies to hoard cash for precautionary motives (see Akguc \& Choi, 2013). Different precautionary motives have been explored by the finance literature, such as higher uncertainty about future cash flows (Bacchetta et al., 2014) or the future macro-economic conditions (Gao \& Grinstein, 2014). Analogously, recent work has

\footnotetext{
${ }^{1}$ Arguments related to the importance of credit availability for M\&As, also called brownfield FDI, have been put forward by Harford (2005), amongst others. As described by Harford (2005), brownfield FDI could depend on industry, technological and regulatory shocks, which in the latter case included Basel regulation on banks' capital requirements, but also on the availability of "capital liquidity to accommodate the asset reallocation" (Harford, 2005, p. 530).
} 
identified higher cash holdings and less investment generally due to financial crises (Campello et al., 2010; Pinkowitz et al., 2013; Song \& Lee, 2012).

As far as the host country is concerned, we assume that greater banking risk (i.e., greater banks' non-performing loans) will also discourage foreign investment in the EA. In this respect, a comprehensive literature already exists on the impact of host countries economic fundamentals on inward FDI (Cai et al., 2018; Bevan and Estrin, 2004; Bellak et al., 2009; Dellis et al., 2017; for a review see Antonakakis and Tondl, 2011). Analogously, we hypothesise that periods of high sovereign yields will lead to lower inward FDI in the EA, via a credit risk channel. This is consistent with existing evidence, which uses sovereign credit ratings as a proxy for sovereign risk, and shows that rating changes affect investment (Chen et al., 2013) and direct investment (Cai et al., 2018). In other words, we expect that when credit risk is higher, this will make investment in the EA less attractive to foreign investors than investments in other, less risky foreign countries. Both our measures of banking and sovereign risk have been widely used by academics, practitioners and policy makers in their periodic assessment of a country credit risk (and financial stability) - especially during the years of the sovereign debt crisis and immediately afterwards. Therefore, these provide an ideal proxy for investors' assessment (both of origin and host countries) of the outstanding financial stability risk in the EA for our sample period.

\section{Methodology}

To analyse the effects of risk and financial stability on FDI, we build a panel dataset including all available bilateral holdings of origin and host countries. Specifically, the dataset contains information on the end-of-the-year positions of 112 foreign direct investor countries in 16 EA countries $^{2}$ over the period ranging from 2009 to 2016 . We take the logarithm of our dependent

\footnotetext{
${ }^{2}$ As in Beck et al. (2016), we consider all Euro Area (EA) countries with the exception of small countries with large financial sectors (i.e., Malta and Luxembourg) and Lithuania, as it joined the EA in 2015.
} 
variable $^{3}$, as well as our proxy variables for sovereign and banking risk, and equations (3.1) and (3.2) below show our chosen regression specification:

$$
\begin{aligned}
& \log \left(F D I_{i h, t}\right)=\alpha+\beta_{0} t+\beta_{1} \log \left(\text { Banking Risk }_{t}\right)+\beta_{2} G_{i h}+\beta_{3} O C_{i h}+\beta_{4} \log \left(\text { Taxes }_{h, t}\right)+ \\
& \varepsilon_{i h, t} \\
& \log \left(F D I_{i h, t}\right)=\alpha+\beta_{0} t+\beta_{1} \log \left(\text { Sovereign Risk }_{t}\right)+\beta_{2} G_{i h}+\beta_{3} O C_{i h}+\beta_{4} \log \left(\text { Taxes }_{h, t}\right)+ \\
& \varepsilon_{i h, t}
\end{aligned}
$$

In the regression equations, $i$ is the country of the foreign direct investor (or origin country), while $h$ denotes the host country. Our main variables of analysis are Banking Risk $k_{t}=$ $\left\{\right.$ Banking Risk $_{i, t}$, Banking Risk $\left._{h, t}\right\}$ consisting of banking sector risk origin countries $i$ and host countries $h$; and, Sovereign Risk ${ }_{t}=\left\{\right.$ Sovereign Risk $_{i, t}$, Sovereign Risk $\left._{h, t}\right\}$ which represents sovereign yields of origin (i) and host countries $(h) . G_{i h}$ includes our set of gravity variables, representing transaction (and information) costs and the cultural bonds connecting the host-origin country pairs. $O C_{i h}$ stands for other control variables (see subsection 4.3 Additional risk measure and main controls), accounting for other motives that could drive direct investment in the EA. Taxesh represents host EA countries tax revenues over GDP, and proxies host countries' fiscal regimes. $t$ is instead a time dummy included to account for time fixed-effects causing abnormal variations in FDI. Finally, $\varepsilon_{i h, t}$ represents the error term. We estimate (3.1) and (3.2) using a least squares approach with Huber-Eiker-White robust standard errors, clustered at the bilateral-country level ${ }^{4}$.

\footnotetext{
${ }^{3}$ As Lane \& Milesi-Ferretti (2008), since several observations in the FDI dataset have value of zero. Before taking the $\log$, we replaced those values of cross-country FDI with the value of 1 USD. This enable us to preserve the greatest possible amount of observations without affecting the reliability of our results.

4 Test for the error component structure have been performed using Wooldridge test for serial correlation (Wooldridge 2010) and Pesaran (2004) test for cross-sectional dependence.
} 


\section{Data}

\subsection{Dependent variable}

The dependent variable used in our paper is the bilateral FDI holdings of 112 direct investor countries in the Euro Area (EA). In a similar vein to Beck et al. (2016), we compose our dataset using end-of-the-year bilateral FDI in the Euro Area, collected from the IMF Coordinated Foreign Direct Investment Survey (CDIS) between 2009 and 2016.

The CDIS is a dataset published by the IMF in 2010 and updated on an annual basis. It has been created to allow a global analysis of cross-country linkages. In the dataset, the IMF provides data on bilateral direct investment holdings of more than 100 countries, participating in the survey. Moreover, disaggregating countries' FDI positions using their immediate counterpart, the CDIS data allows for a cross-country and over time comparison of FDI positions (Damgaard \& Elkjaer 2017). Consequently, we are in a position to observe bilateral direct investment, disentangling effects and drivers of origin and host countries. This allows for a better identification of effects as compared to standard approaches used in the literature which implicitly assumes that host characteristics are the main drivers.

To emphasise, the main advantage of this dataset is that it enables us to disentangle origin and destination of FDI. This is of course necessary in order to be able to test our hypothesis. Our hypothesis requires use information on the host and origin country simultaneously as determinants of the direct investment. As highlighted in Beck et al. (2016), the understanding of the causes and origins of these foreign investors' positions is of crucial importance for policy makers. For instance, with respect to central bank policy, while intra Euro Area flows can be easily managed by the ECB, significant variations of outside (non-EA) FDI - particularly 'sudden stops' in FDI - could potentially undermine central banks' goals and targets. As a matter of fact, as pointed out by the authors, intra-EA capital allocation can be more easily supervised and managed by the ECB through Target balances and variations in 
official flows. In the following sections, we exploit the bilateral properties of our data to compare bilateral inward FDI in "stressed" and "non-stressed" Euro Area countries (cf. Table 2) from all countries with inward FDI.

Of course, there are some caveats to mention related to the use of this data which we try to minimise. Firstly, FDI data from the CDIS is unadjusted for valuation effects. Secondly, to increase the representativeness of the data, CDIS include data on both listed and unlisted firms, however, different valuation methods, especially for unlisted firms, can generate significant geographical asymmetries in the data (Damgaard \& Elkjaer, 2017). Thirdly, data from the CDIS is not adjusted for exchange rate effects. Therefore, changes in stock positions could potentially reflect EUR/USD exchange rate movements. As Beck et al. (2016, p.452) notes, "purging these valuation effects from the stock positions would require detailed knowledge about the currency and maturity composition of the holdings, on which data do not exist." Finally, as the dataset discloses FDI by immediate counterpart economy, it also includes transactions performed by MNEs through Special Purpose Entities (SPEs), often for tax avoidance purposes or financial engineering (Dellis et al. 2017; Damgaard \& Elkjaer, 2017; Damgaard et al., 2018; Haufler et al., 2018; Egger et al., 2018). This effect might be greater in smaller countries that have relatively large financial sectors.

Therefore, as remarked on by Beck et al. (2016) and Milesi-Ferretti et al. (2010), ideally we would use a panel dataset collecting consolidated bilateral flows, adjusted for exchange rate effects and recorded on a residence (locational) basis, where 'the 'ultimate risk' basis implies that the borrower is the entity ultimately responsible for the liability" (Milesi-Ferretti et al., 2010: 21), but such data does not exist. Thus, to minimise the aforementioned biases and avoid data distortions, following Beck et al. (2016) we exclude countries considered major tax

\footnotetext{
${ }^{5}$ Defined according to their exposure to the European sovereign debt crisis (see Table 7 - Summary Statistics, for reference).
} 
heavens and smaller countries with proportionately large financial sectors and we use stock data. ${ }^{6}$ Finally, to mitigate the impact of the exchange rate channel, we build our baseline model 'in levels' and test the robustness of our results to economic growth, using GDP per capita in USD. Note that Table 7 presents summary statistics for our dependent variable and risk measures for GIIPS and non-GIIPS Euro Area countries.

For the sake of transparency and completeness, in Figure 1, we also present aggregated - non-bilateral - data on FDI flows collected from UNCTAD. Such flow data, unfortunately, does not suit our empirical study due to its opacity regarding the nationality of the foreign direct investor (origin country), limiting its use to a descriptive assessment of FDI behaviour during and after the crisis. Interestingly, looking at FDI inflows in the Euro Area, we observe a substantial drop during the GFC. Subsequently, it appears to stabilise (see Figure 1) and stagnate until early 2015, when it surges. Recent work on FDI has also observed this pattern and argued that direct investment appears to differ in its drivers from all other forms of international investments and has proved considerably more resilient than portfolio flows to domestic countries during crises (Milesi-Ferretti \& Tille, 2010; Forster et al., 2011; Darvas et al., 2013; Pegkas, 2015; Sondermann \& Vansteenkiste, 2019). Several authors observed this intriguing response of FDI to the crisis. Habib and Venditti (2018) found that FDI is less sensitive to global risk and that it seems to "follow a cycle which is different from other asset classes" (Habib \& Venditti, 2018:17). Sondermann and Vansteenkiste (2019) controlled for both the GFC and for the sovereign debt crisis found evidence of a low sensitivity of FDI in the EMU to their domestic crisis dummies. Recent work from Milesi-Ferretti and Tille (2010), considering just the period of the GFC, yielded also similar results. This per se seems to provide some validation for our hypotheses on the importance of other factors of risk, other than the domestic ones.

\footnotetext{
${ }^{6}$ For a detailed overview see Appendix A.0.2.
} 


\subsection{Independent variables}

As said, we focus on specific risks for MNEs involved in FDI. Particularly, we look at financial stability, arising from concerns about a fragile banking sector and high sovereign indebtedness with implications for the overall economy and consequently on the expected investment return (Acharya et al., 2018).

Specifically, as proxy for bank risk taking, we opt for using the ratio of banks nonperforming loans-over-total loans (NPL ratio), which measures the outstanding banks credit risk, by quantifying the vulnerable portion of banks' assets. Hence, this constitutes a straightforward measure of banks' risk. NPLs affect bank lending through at least three main channels: (i) eroding banks' profitability, as NPLs generate less income for banks and require more provisions, reducing their net income; (ii) reducing banks available capital, since banks' capital adequacy regulation require banks to allocate capital buffers proportionally to the risk of their assets; (iii) greater funding costs, arising from the worsening of banks credit profile, as a result of their impaired balance sheet (Aiyar \& Monaghan, 2015). European Institutions significantly increased their focus on reducing the level of banks' non-performing loans of EA banks after the GFC (see Deslandes et al., 2018, for a review of European institutions debate and initiatives on NPLs). Higher NPLs impact the private sector, particularly in countries relying heavily on bank financing such as within the Euro Area, making access to credit harder and more expensive, especially for SMEs (ibid.). Data on non-performing loans ratio is collected from the 'Financial Institutions: Stability' indicators of the World Bank Global Financial Development DataBank.

To measure sovereign risk we use instead 10-year government bond yields. This is a widely agreed proxy for sovereign risk (Arghyrou \& Kontonikas, 2012; Bernoth \& Erdogan, 2012; Afonso et al., 2014, 2018). Recent works, by e.g. Cai et al. (2018), have examined the 
relation between sovereign credit ratings and FDI. While using credit ratings is a reasonable measure, we believe that using sovereign bond yields for our purposes is a superior approach, as it reflects the market perspective and should react more quickly to changes in relevant information - see Barroso (2010) and De Vries \& de Haan (2016). To maximise our sample coverage, we merge data from IMF International Financial Statistics (IMF IFS), OECD Financial Statistics, CEIC, Oesterreichische Nationalbank, and Bloomberg.

Figure 2 shows the evolution of our sovereign and banking risk measures. We observe a decline outside the EA zone and for non-GIIPS countries, whilst for GIIPS countries, sovereign risk increased dramatically until mid-2012. At the peak of the sovereign debt crisis, sovereign yields in GIIPS countries being more than 3 times higher than non-GIIPS ones, and still twice higher at the end of 2016. After the extraordinary commitment from the ECB to stabilise the EMU, spreads began to fall. They remain, however, at elevated levels by the end of our sample period. Non-performing loans-over-total loans also show a similar pattern. Therefore, even if in 2016 non-performing loans of EA banks were still at a much higher than in 2009, we can observe that in 2013, just after the announcement of the Outright Monetary Transactions (OMT) program and the creation of the Banking Union, they either stabilised (in non-GIIPS countries) or substantially reduced (in GIIPS). Moreover, the substantial variation that we detect in both our measures of risk is certainly something that we can exploit in our analysis.

As evident from Figure 2, however, neither financial stability risk nor the following recovery is homogeneous across the EA. In particular, sovereign yields and non-performing loans remain considerably higher in GIIPS countries than in non-GIIPS countries, leaving overall risk in the EA at high levels. In light of this, we question whether financial stability risk in EA might just be driven by risk in the former group, rather than in the latter, but then affecting the EA as a whole. To address this empirical question, in our empirical analysis, we 
test the impact of financial stability risk on inward FDI considering both the EA as a whole and separating it between GIIPS and non-GIIPS countries (see Tables 1 and 2).

Overall, the implication of these graphs are twofold: on the one hand, they highlights again the importance of the 'regulator' in improving sovereign and banks' safeness - as the ECB Outright Monetary Transactions (OMT) and Quantitative Easing (QE) programs have reduced both EA countries average yields and banks' exposure to NPLs; on the other hand, the graphs also supports the hypothesis of a strong fragmentation within the Euro Area, arising from significant differences in both measures of risk.

\subsection{Additional risk measure}

For robustness reasons, we re-estimate our models using a different bank risk measure. We select a popular measure that has been frequently used to measure the outstanding risk of banks: banks Regulatory Capital to Risk-Weighted Assets. This, we think that certainly is a focused measure of the stability of each country's banking system, particularly given its contemporary policy attention. Our idea is that if banks are asked to hold more regulatory capital, this will likely have a detrimental impact on the amount lent to firms (Fraisse et al. 2017; De Goede, 2004; Flinders and Buller, 2006; Dovis et al., 2016).

In more detail, Regulatory Capital to Risk-Weighted Assets measures the aggregate amount of core capital allocated by a country's banking sector as a buffer on their risky assets. This variable is commonly used in the banking literature to assess the stability of the banking sector (see De Bruyckere et al. (2013), Afonso et al. (2018), Delatte et al. (2017) and reflects policymakers attempts to address excessive bank risk taking through greater capital buffers. In order to maximise the country sample, we combined data from the IMF Financial Soundness Indicators and World Bank Global Financial Development DataBank. 
In Figure 3 we observe that, after the GFC, greater worldwide regulation of the banking sector led banks globally to increase the amount of capital allocated as a buffer for their risky assets. The new regulatory frameworks have considerably shrunk the credit availability of banks, hence resulting in lower bank risk taking. Also, in the case of our latter variable, the enhancement of banks solvency appears as especially pronounced post-OMT and Banking Union announcements, which is sign of an improvement in banks safety. However, overall we observe a similar picture to that presented in Figure 2, disclosing a significantly higher banking risk in GIIPS countries as opposed to non-GIIPS, represented by much riskier positions of banks (supported by thinner capital buffers).

\section{[Insert Figures 1, 2 and 3 about here]}

\subsection{Main Controls}

Finally, we include in our baseline model several additional control variables. In particular, we include standard gravity model variables, controlling both for information frictions and transaction costs arising from the individual FDI bilateral transactions and for cultural links, arising from a shared historical background of origin and host countries. The inclusion of gravity model variables is a standard practice in the literature on bilateral cross-border investment, especially when studying FDI. Portes \& Rey (2005) provide evidence that gravity variables proxying country size and transaction costs - arising from informational frictions differences in technology - might explain up to $83 \%$ of bilateral cross-country equity flows (Martin \& Rey 2004, Portes \& Rey 2005). Daude \& Fratzscher (2008) confirm that FDI is much more dependent on informational frictions than portfolio flows. With respect to gravity variables, we follow Lane \& Milesi-Ferretti (2008) amongst others and include several control variables, such as: (i) a dummy variable identifying whether the analysed countries share the 
same official language; (ii) a control for the physical distance between the countries; (iii) a dummy variable disclosing whether the considered countries share a geographical border; (iv) a dummy variable identifying countries with a common religion; (v) a control variable for the time difference between the analysed countries; and (vi) a dummy variable determining country pairs with a common legal origin.

In addition to the gravity variables, we also added supplementary control variables, identifying other potential drivers of FDI. Following Lane \& Milesi-Ferretti (2008), we controlled for the trade link between origin and EA countries, using the average bilateral import of the EA from the considered origin countries between 2009 and 2016. While, as suggested by Davis et al. (2000), we included correlation between host and origin countries GDP growth and between host countries' stock market capitalisation and origin countries GDP growth. Specifically, the former variable accounts for diversification incentives (benefits) which could lead origin countries to FDI, while the latter to control for hedging incentives, arising from potential negative output shocks in the origin country. We also control for origin countries wealth and financial sector development, using respectively the second lag of origin countries GDP per capita and financial market capitalisation-over-GDP. This is motivated in the case of wealth by the idea that, as risk aversion is decreasing with wealth, we expect richer countries to be strongly driving FDI (Lane \& Milesi-Ferretti, 2008). In the case of financial market development instead, this is based on the assumption that financial sophistication can facilitate foreign investment - see Lane \& Milesi-Ferretti (2001). Lastly, since push factors from the home country may include the need to escape domestic taxes or high exchange rate fluctuations, we added a control for host countries fiscal policies, using host countries' government tax revenues-over-GDP, and for exchange rate movements, using the standard deviation of bilateral currencies (for more details on the computation of our control variables, see Appendix A.0.1). 


\section{Results}

In this section, we present and discuss the estimation results of equations (3.1) and (3.2). Table 1 contains our main specification where we focus on the two core risk variables - NonPerforming Loans and 10-Year Sovereign Bond Yields. Given the bilateral nature of our data, we estimate for each risk proxy, two equations (3.1) and (3.2), for the origin and host country risk, respectively. Doing this, we can assess which one is the most relevant for FDI, i.e. whether risk in the origin country or in the host country matter the most, or whether they matter in a similar fashion. In Table 2, we split our sample into GIIPS and non-GIIPS countries. The separate consideration of our full sample of countries is a standard step performed by literature analysing the geographical pattern of capital flows - see Milesi-Ferretti et al. (2010), Beck et al. (2016) - and is especially crucial for our study. This is justified by the considerable difference that we observe in the levels of sovereign and banking risk within the Monetary Union (see Figure 2).

Considering Table 1 first of all, the included gravity variables are statistically significant and have the expected sign. In line with the previous literature (Beck et al., 2016; Daude \& Fratzscher, 2008; Martin \& Rey, 2004; Portes \& Rey, 2005), both average import and standard gravity variables - proxying information and transaction costs - are important drivers of FDI. Sharing the same official language and high proximity, increase foreign direct investment. This is testified by comm_lang dummy with a coefficient of about 1.4 in both columns (1) and (2) and by the two variables of $\log$ (distance) and contig ${ }^{7}$. The latter variables have respectively coefficients of -0.95 in column (1) (and 0.6 in column (2)) - in the case of $\log ($ distance $)$ - and 2.10 in column (1) (and 1.37 in column (2)) - for contig. All the coefficients are supporting our "story" and are significant at 1\% level. Similarly, we found that cultural and

\footnotetext{
${ }^{7}$ We tested our result also using the time difference between host and origin countries, the results are unaffected, and the coefficients are similar to those of the $\log$ (distance) variable. The two variables have not been included together because of the high correlation between them.
} 
institutional affinity also positively affect FDI in the EA. Specifically, having a shared religion or colonisation history positively influence FDI as well as sharing a legal origin. Apart from the common religion dummy, however, the other two variables are mostly found nonsignificant. Similarly, also not significant appear to be the correlation in host and origin countries GDP growth and government tax revenues-over-GDP, ruling out the diversification incentive as potential driver for FDI, and the tax evasion motif. As expected, we found exchange rate volatility as extremely significant, both economically and statistically, as 1 percent increase in volatility in the origin currencies-over-euro lead to an almost equivalent loss in foreign direct investment in EA countries (the coefficients are -1.17 in column(1) and 0.92 in column (2)).

\subsection{Country risk impact on FDI}

Considering next the effect of greater non-performing loans in banks' balance sheet on inward FDI - column (1), the origin country coefficient estimate in column (1) is statistically significant and has negative sign (-0.16), implying a reduction of FDI volume invested by MNEs. To the contrary, we observe that the coefficient estimate capturing the risk of host countries is not significant. These results do not confirm our hypothesis, highlighting that origin country risk hugely matters when dealing with FDI. As discussed in Section 1, increases in non-performing loans are likely to lead to less credit availability, particularly for firms wishing to invest overseas where imperfect knowledge considerations are greater. This matters much more in origin countries, where a closer institutional affinity and familiarity between banks and MNEs may well see more FDI financing take place than in host markets. In other words, our findings present an asymmetric effect across origin and host countries, resulting in FDI in the origin country being predominantly carried out via local banks, hence insensitive to host countries' risk. 
Continuing to focus on Table 1 and examining 10-year Sovereign Bond Yields, we can observe that both coefficients in column (2) of Table 1 are statistically significant and present a negative sign. This implies that higher sovereign risk, both domestically as well as in the host country, results in lower FDI in the Euro Area and confirms the first hypotheses. An increase in either origin or host country sovereign risk, is likely to decrease the FDI of MNEs giving a higher motive for companies to engage in less risk-taking and accumulate more cash holdings. Analogously, recent work has identified higher cash holdings and less investment generally due to financial crises (Song \& Lee, 2012). Notably when comparing the magnitude of the coefficient estimates in column (2), we observe that the coefficient of the origin country is bigger than the coefficient of the host country. In particular, our regression model predicts an increase of $1 \%$ in 10 years government bonds' yields in origin countries to result in a 1.4 percent decrease in FDI, while an equivalent increase in host countries bond yields to result in a much less strong impact - a 0.46 percent decrease (more than three times smaller). Hence, it appears that origin countries risk is considerably more relevant than that of the host country, also providing evidence of the key role held by banks in financing global FDI - via the socalled lending channel - discussed by the existent literature (Bridges et al., 2014; Bacchetta et al., 2014; Harford, 2005; Aiyar \& Monaghan, 2015; Fraisse et al., 2017).

In Table 2, we have a closer look at the EA countries and split the sample into GIIPS (i.e., stressed) and non-GIIPS (i.e., non-stressed) Euro Area countries. Given the sharper increase of sovereign risk for GIIPS countries over our sample period, the effect of such risk should be more pronounced in GIIPS countries than in non-GIIPS countries. Table 2 contains the relevant estimation results. Again, our main hypotheses, are confirmed. We confirm that banking risk and sovereign risk are both relevant. Banking risk is relevant for the origin country only, with respect to non-GIIPS countries (see column (1)), while sovereign risk is important for both origin and host country in all specifications (see column (2)). Surprisingly, the 
coefficient estimates of our chosen risk variables become larger in absolute magnitude in the non-GIIPS country sub-sample. This might be attributed to foreign investors' awareness of GIIPS greater levels of non-performing loans, hence to a previous embodiment of this piece of information. Undoubtedly, FDI in GIIPS countries, whose banking sector has been severely disrupted by the crises, seem to be also sensitive to an increase in banking sector stability. For example, an increase in banks' capital buffers of 1 percent seem to increase FDI in GIIPS of 0.16 percent. Sovereign yield shocks, among other variables, have instead a much stronger impact on FDI in GIIPS. This is coherent with a much stronger impact that the sovereign debt crisis had on the EA periphery, and with the numerous sovereign rating downgrades that took place in the years of analysis.

This finding of an asymmetric behaviour of FDI in the EA, which came out contraposing direct investment in stressed as opposed to non-stressed EA countries, we believe has very important policy implications. This, as it increases the fragmentation within the European Monetary Union (EMU), both in terms of growth potential and in terms of availability of public finances, putting additional risk on GIIPS countries, hence enhancing political and financial market tensions in the European Union (Beck et al., 2016). Furthermore, this asymmetry between investor behaviour - mostly arising from origin countries significantly limit ECB capital flow management policies, requiring a narrower and more specific scope.

Several alternative specifications have been estimated, where we added various controls and fixed effects (e.g. we tested all variables in one regression, we excluded intra-EA FDI, and so on). Results are qualitatively unaffected by these alterations and are available on request.

[Insert Tables 1 and 2 around here] 


\section{Robustness}

In the paper, we present several robustness tests of our baseline model results.

In Table 3 below we include an additional proxy for banking risk discussed previously in Section 4.4. Overall, our results and conclusions remain unaffected with further support provided for our hypotheses. In particular, also Regulatory Capital-over-Risk-Weighted Assets confirms that the origin country's, as opposed to the host country's, banking risk situation matters for FDI decisions.

In Table 4, we test the possibility that a hedging incentive (see in columns (1) and (2)) or greater investors' risk aversion are driving FDI positions of origin countries (in columns (3) and (4)) in the Euro Area. Therefore, following Lane \& Milesi-Ferretti (2008), Davis et al. (2000), in columns (1) and (2) we add to the baseline models the correlation between host countries financial market capitalisation and origin countries GDP per capita - proxy for a hedging incentives. In case of a hedging channel, we expect to observe the variable to have a negative coefficient, meaning that when domestic conditions in origin countries' financial markets are impaired MNEs have the incentive to invest abroad. This would further support our theory on FDI being driven considerably more by origin country conditions, rather than host country ones. In columns (3) and (4), we test instead the relevance of origin countries' economic wealth as driver for FDI. According to Lane \& Milesi-Ferretti (2008), since FDI involves risk, and risk aversion is a decreasing function of economic wealth, greater economic wealth should have a positive impact on origin countries FDI (i.e. richer countries would display greater levels of FDI).

Overall, in Table 4, we find weak evidence of a hedging channel and strong support for the importance of origin countries' wealth. Looking at columns (1) and (2) of Table 4, we find that a 1 percent increase in the synchronisation host-origin countries' economic conditions implies a decrease in 0.44 percent in FDI. The result, however, is only significant at $10 \%$ level 
in column (1), it is not significant instead in the second regression. In accordance with the findings of Lane \& Milesi-Ferretti (2008), we confirm the importance of countries' wealth, which we proxy using second lag of origin countries GDP per capita. Therefore, we find that 1 percent increase in GDP per capita $(t-2)$ results in a 0.6 increase in FDI in column (3) - and a 0.5 increase in column (4). Moreover, in both regressions model our core signs and economic significance remain unaffected.

In Table 5 and 6, to further ensure that that our baseline regressions capture country specific risk - of origin and host countries - as opposed to global risk, we perform two additional tests. Firstly, we use two measures of global risk aversion (the VIX and the World Uncertainty Index ${ }^{8}$ ) capturing “push” (or common) risk factors, as opposed to "pull” (or country-specific) ones - already embedded in our baseline model. Secondly, to account for any cross-sectional variation arising at the host country level, we use host country and time fixed effects and we replace our core explanatory variables (banking and sovereign risk) with the corresponding differences between origin and host country risk. This is a standard practice of the gravity model literature (e.g. Beck et al. (2016); Carril-Caccia \& Pavlova (2018)).

Tables 5 and 6 again confirms the validity of our results, which remain qualitatively unaffected both after the inclusion of global risk variables and when we replace individual countries' banking and sovereign risk with the difference between origin and host countries' values of these variables ${ }^{9}$. Therefore, we still find that origin country characteristics outweigh those of the host when trying to explain inward FDI in the EMU.

\footnotetext{
${ }^{8}$ In order to determine the components of banking and sovereign risk which are not determined by global "push" factors, we used a two-stage approach. Specifically, in the first stage we separately regressed non-performing loans ratio and 10-years government bond yields on the VIX. The residuals from the first stage are then used in the second stage regression as additional explanatory variables for respectively the component of global risk, not captured by either banking or sovereign risk.

${ }^{9}$ In Table 6, instead of contraposing origin and host country risk factors, we include 'Diff_bank_risk' computed as the difference in 'NPL ratio_orig' and 'NPL ratio_host' as banking risk measure; and, 'Diff_sov_risk' computed as the difference in 'Sovereign yields_orig' and 'Sovereign yields_host' as sovereign risk measure. The results have been supplemented with both gravity and control variables previously explained, as well as time $(t)$ and host country fixed effects $(i)$.
} 
Lastly, when estimating FDI movements within a monetary union, it might be relevant to distinguish Euro Area FDI inflow from non-Euro Area FDI inflow. Hence we estimate the regression from Table 2 with inward FDI from non-Euro Area countries only (see Table 12 Appendix 2). Our results suggest that even when excluding intra-EA FDI allocation, origin country banking and sovereign risk conditions remain the main causes of lower FDI in the EA.

[Insert Tables 3, 4, 5 and 6 around here]

\section{Conclusions}

In this paper we investigate how elevated sovereign and banking risk affect Euro Area countries' ability to attract foreign investment. In analysing this type of investment, the international finance and international business literature have examined several determinants of FDI, including those arising from political, social, geographical, technological, regulatory and/or firm specific spheres (Alam \& Zulfiqar, 2013; Borin \& Mancini, 2016; Dellis et al., 2017; Narula, 2014). However, financial sector risk has often been considered less important

and consequently, the risks to FDI, emanating both from recent financial crises (e.g., the GFC and sovereign debt crisis) and any policy responses to these, have been underexplored. To remedy this, we inspect inward FDI stock in the Euro Area between 2009 and 2016 in relation to various measures of financial stability, including non-performing loans and sovereign yields. Most importantly, we newly discriminate between effects emanating from the host and origin country.

Interestingly, when we analyse the impact of non-performing loans across both origin and host country banks, we find that host country banking risk is never significant in any our regression models or robustness tests. By contrast, origin country banking risk appears as an important determinant of the volume of FDI received by Euro Area countries. We attribute this finding to a 'leverage channel', whereby firms borrow from banks to finance investment, including FDI. Drawing on the banking literature, we suggest that banks' lending in origin 
countries will be considerably tighter when banks in their home countries display high levels of NPL, or, more generally speaking, in moments of greater uncertainty.

When we analyse sovereign risk of origin and host countries and inspect how this affects FDI, our findings are mixed. As a matter of fact, greater sovereign risk in either origin countries or hosts (EMU countries) leads to lower FDI positions in the Euro Area. However, in absolute magnitude, sovereign risk of the origin country matters more than that of the host country; an interesting finding given the typical weight placed on the importance of the host country characteristics in attracting FDI. We think that our findings are consistent with the literature on uncertainty and precautionary motives, whereby an increase in domestic country risk encourages its own MNEs to engage in less risk-taking. On the other hand, an increase in host country yield arguably implies that other destinations appear more attractive.

When the Euro Area sample is separated into two subsamples representing non-stressed and stressed (i.e., Greece, Ireland, Italy, Portugal and Spain) countries, our findings remain qualitatively unaffected in our baseline regressions, as well as in all our robustness tests. Additionally, the reduction in FDI from origin countries with respect to sovereign risks, is clearly greater in the stressed case. The opposite is found with respect to banking risk, as an increase in such risks has a greater impact on non-GIIPS ability to attract FDI. However, origin country risk always appears to matter more than that of the host.

Overall, our theoretical arguments and empirical results show that financial stability, both in origin and host countries, matters for FDI. This study provides further illustration of the dynamics of such processes, focusing on the effects of variations in bank-related risk, a key systemic feature where the range of regulatory choices is somewhat circumscribed. We would encourage policymakers in countries that seek to attract FDI not only to be mindful of the domestic conditions that lead to lower sovereign risk, but also to be cognisant of the changing financing environment that MNEs may face in their home countries, and, indeed, in deciding 
which countries to target in seeking FDI. Additionally, we suggest the importance of addressing the asymmetric behaviour of FDI within the core and periphery of the Euro Area. Improving Euro Area convergence with respect to inward foreign investment, we believe could substantially reduce its fragmentation as well as curtail political and financial market tensions in the European Union.

\section{References}

Acharya, V.V., Shin, H.S. and Yorulmazer, T., 2007. Fire-sale FDI. Centre for Economic Policy Research.

Acharya, V., Engle, R. \& Pierret, D. (2014), 'Testing macroprudential stress tests: The risk of regulatory risk weights', Journal of Monetary Economics 65, 36-53.

Acharya, V. V., Eisert, T., Eufinger, C. \& Hirsch, C. (2018), 'Real effects of the sovereign debt crisis in europe: Evidence from syndicated loans', The Review of Financial Studies 31(8), $2855-2896$.

Afonso, A., Arghyrou, M. G., Gadea, M. D. \& Kontonikas, A. (2018), "whatever it takes" to resolve the european sovereign debt crisis? bond pricing regime switches and monetary policy effects', Journal of International Money and Finance 86, 1-30.

Afonso, A., Arghyrou, M. G. \& Kontonikas, A. (2014), 'Pricing sovereign bond risk in the european monetary union area: an empirical investigation', International Journal of Finance \& Economics 19(1), 49-56.

Aguiar, M. and Gopinath, G., 2005. Fire-sale foreign direct investment and liquidity crises. Review of Economics and Statistics, 87(3), pp.439-452.

Aiyar, M. S. \& Monaghan, M. D. (2015), A strategy for resolving Europe's problem loans, International Monetary Fund. 
Akguc, S. \& Choi, J. J. (2013), 'Cash holdings in private and public firms: Evidence from Europe'.

Alam, A. \& Zulfiqar Ali Shah, S. (2013), 'Determinants of foreign direct investment in OECD member countries', Journal of Economic Studies 40(4), 515-527.

Alquist, R., Mukherjee, R. and Tesar, L., 2013. Fire-sale FDI or Business as Usual? (No. w18837). National Bureau of Economic Research.

Antonakakis, N. and Tondl, G., 2011. Do determinants of FDI to developing countries differ among OECD investors? Insights from Bayesian model averaging (No. 76). FIW Working Paper.

Arghyrou, M. G. \& Kontonikas, A. (2012), 'The EMU sovereign-debt crisis: Fundamentals, expectations and contagion', Journal of International Financial Markets, Institutions and Money 22(4), 658-677.

Bacchetta, P., Benhima, K. \& Poilly, C. (2014), 'Corporate cash and employment'. Barroso, J. (2010), 'Statement to the european parliament prior to the meeting of the heads of state and government of the euro area', European Parliament Plenary, Brussels 5.

Banti, C. and Phylaktis, K., 2019. Global liquidity, house prices and policy responses. Journal of Financial Stability.

Beck, R., Georgiadis, G. \& Gräb, J. (2016), 'The geography of the great rebalancing in euro area bond markets during the sovereign debt crisis',Journal of Empirical Finance 38, 449-460. Beirne, J. and Fratzscher, M., 2013. The pricing of sovereign risk and contagion during the European sovereign debt crisis. Journal of International Money and Finance, 34, pp.60-82. Bernanke, B. \& Gertler, M. (1990), 'Financial fragility and economic performance', The Quarterly Journal of Economics 105(1), 87-114.

Bernoth, K. \& Erdogan, B. (2012), 'Sovereign bond yield spreads: A time-varying coefficient approach', Journal of International Money and Finance 31(3), 639-656. 
Bordo, M. D. \& Jeanne, O. (2002), Boom-busts in asset prices, economic instability, and monetary policy, Technical report, National Bureau of Economic Research.

Borin, A. \& Mancini, M. (2016), 'Foreign direct investment and firm performance: an empirical analysis of Italian firms', Review of World Economics 152(4), 705-732.

Bridges, J., Gregory, D., Nielsen, M., Pezzini, S., Radia, A. \& Spaltro, M. (2014), 'The impact of capital requirements on bank lending'.

Brun, M., Fraisse, H., Thesmar, D. et al. (2013), 'The real effects of bank capital requirements', Débats économiques et financiers 8, 3-26.

Cai, P., Gan, Q. \& Kim, S.-J. (2018), 'Do sovereign credit ratings matter for foreign direct investments?', Journal of International Financial Markets, Institutions and Money 55, 50-64.

Campello, M., Graham, J. R. \& Harvey, C. R. (2010), 'The real effects of financial constraints: Evidence from a financial crisis', Journal of financial Economics 97(3), 470-487.

Carril-Caccia, F. and Pavlova, E., 2018. Foreign direct investment and its drivers: a global and EU perspective. ECB Economic Bulletin, (4).

Chen, S.-S., Chen, H.-Y., Chang, C.-C. \& Yang, S.-L. (2013), 'How do sovereign credit rating changes affect private investment?', Journal of Banking \& Finance 37(12), 4820-4833.

Chen, X., Kontonikas, A. \& Montagnoli, A. (2012), 'Asset prices, credit and the business cycle', Economics Letters 117(3), 857-861.

Claeys, P. and Vašíček, B., 2014. Measuring bilateral spillover and testing contagion on sovereign bond markets in Europe. Journal of Banking \& Finance, 46, pp.151-165.

Damgaard, J. \& Elkjaer, T. (2017), The global FDI network: searching for ultimate investors, International Monetary Fund.

Damgaard, J., Elkjaer, T. and Johannesen, N. (2018). Piercing the veil. Finance and Development, 55(2), pp.51-53. 
Darvas, Z., Hüttl, P., Merler, S. and Walsh, T. (2015). Analysis of developments in EU capital flows in the global context. Bruegel Study, 3.

Daude, C. \& Fratzscher, M. (2008), 'The pecking order of cross-border investment', Journal of International Economics 74(1), 94-119.

Davis, S. J., Nalewaik, J. \& Willen, P. (2000), On the gains to international trade in risky financial assets, Technical report, National Bureau of Economic Research.

De Bruyckere, V., Gerhardt, M., Schepens, G. \& Vander Vennet, R. (2013), 'Bank/sovereign risk spillovers in the European debt crisis', Journal of Banking \& Finance 37(12), 4793-4809. De Goede, M., 2004. Repoliticizing financial risk. Economy and Society, 33(2), pp.197-217. De Vries, T. \& de Haan, J. (2016), 'Credit ratings and bond spreads of the giips', Applied Economics Letters 23(2), 107-111.

Delatte, A.-L., Fouquau, J. \& Portes, R. (2017), 'Regime-dependent sovereign risk pricing during the euro crisis', Review of Finance 21(1), 363-385.

Dellis, K., Sondermann, D. \& Vansteenkiste, I. (2017), 'Determinants of FDI inflows in advanced economies: Does the quality of economic structures matter?'.

Egger, P., Eggert, W. and Winner, H., 2010. Saving taxes through foreign plant ownership. Journal of International Economics, 81(1), pp.99-108.

Flinders, M. and Buller, J., 2006. Depoliticisation: Principles, tactics and tools. British politics, 1(3), pp.293-318.

Forster, K., Vasardani, M.A. and Ca' Zorzi, M., 2011. Euro area cross-border financial flows and the global financial crisis. ECB Occasional Paper, (126).

Fraisse, H., Lé, M., Thesmar, D. et al. (2017), 'The real effects of bank capital requirements'. Galanos, G. and Poufinas, T., 2018. Impact of FDI in the Fiscal Adjustment Process. International Advances in Economic Research, 24(3), pp.265-277. 
Gao, J. \& Grinstein, Y. (2014), 'Firms' cash holdings, precautionary motives, and systematic uncertainty', Available at SSRN 2478349.

Habib, M.M. and Venditti, F., 2018. The global financial cycle: implications for the global economy and the euro area. Economic Bulletin Articles, 6.

Harford, J. (2005), 'What drives merger waves?', Journal of financial economics 77(3), 529560.

Haufler, A., Mardan, M. and Schindler, D., 2018. Double tax discrimination to attract FDI and fight profit shifting: The role of CFC rules. Journal of International Economics, 114, pp.2543.

Krugman, P., 2000. Fire-sale FDI. In Capital flows and the emerging economies: theory, evidence, and controversies (pp. 43-58). University of Chicago Press.

Lane, P. R. \& Milesi-Ferretti, G. M. (2001), 'The external wealth of nations: measures of foreign assets and liabilities for industrial and developing countries', Journal of International Economics 55(2), 263-294.

Lane, P.R. and Milesi-Ferretti, G.M., 2008. International investment patterns. The Review of Economics and Statistics, 90(3), pp.538-549.

Martin, P. \& Rey, H. (2004), 'Financial super-markets: size matters for asset trade', Journal of international Economics 64(2), 335-361.

Merler, S. and Pisani-Ferry, J., 2012. Who's afraid of sovereign bonds? (No. 2012/02). Bruegel Policy Contribution.

Milesi-Ferretti, M. G.-M., Tamirisa, M. N. T. \& Strobbe, M. F. (2010), Bilateral Financial Linkages and Global Imbalances: A Viewon the Eve of the Financial Crisis, number 10-257, International Monetary Fund.

Milesi-Ferretti, G.M. and Tille, C., 2011. The great retrenchment: international capital flows during the global financial crisis. Economic policy, 26(66), pp.289-346. 
Narula, R. (2014), Globalization and technology: Interdependence, innovation systems and industrial policy, John Wiley \& Sons.

Neto, D.G. and Veiga, F.J., 2013. Financial globalization, convergence and growth: The role of foreign direct investment. Journal of International Money and Finance, 37, pp.161-186.

Pegkas, P., 2015. The impact of FDI on economic growth in Eurozone countries. The Journal of Economic Asymmetries, 12(2), pp.124-132.

Pesaran, M. H. (2004), 'General diagnostic tests for cross section dependence in panels'.

Pinkowitz, L., Stulz, R. M. \& Williamson, R. (2013), 'Is there a us high cash holdings puzzle after the financial crisis?'.

Portes, R. \& Rey, H. (2005), 'The determinants of cross-border equity flows', Journal of International Economics 65(2), 269-296.

Razin, A. and Sadka, E., 2007. Productivity and Taxes as Drivers of FDI (No. w13094). National Bureau of Economic Research.

Rey, H. and Trilemma, D., 2013, August. The global financial cycle and monetary policy independence. In Economic Policy Symposium, Federal Reserve Bank of Kansas City.

Shatz, H. \& Venables, A. (2000), 'The geography of international investment. vol. 2338', Washington, DC: World Bank.

Shin, H.S., 2012. Global banking glut and loan risk premium. IMF Economic Review, 60(2), pp.155-192.

Shukla, P. \& Cantwell, J. (2018), 'Migrants and multinational firms: The role of institutional affinity and connectedness in FDI', Journal of World Business 53(6), 835-849.

Sondermann, D. and Vansteenkiste, I., 2019. Did the euro change the nature of FDI flows among member states?. ECB Working Paper

Song, K. R. \& Lee, Y. (2012), 'Long-term effects of a financial crisis: Evidence from cash holdings of East Asian firms', Journal of Financial and Quantitative Analysis 47(3), 617-641. 
Weitzel, U., Kling, G. and Gerritsen, D., 2014. Testing the fire-sale FDI hypothesis for the European financial crisis. Journal of International Money and Finance, 49, pp.211-234.

Wooldridge, J. M. (2010), Econometric analysis of cross section and panel data, MIT press. 


\section{Tables}

Table 1

Estimation results on the impact of banking and sovereign risk on inward FDI in the EMU by OLS.

\begin{tabular}{|c|c|c|}
\hline \multicolumn{3}{|c|}{ Country Risk } \\
\hline & Banking Risk & Sovereign Risk \\
\hline & (1) & (2) \\
\hline & $\log (\mathrm{FDI})$ & $\log (\mathrm{FDI})$ \\
\hline log (NPL ratio_orig) & $-0.163 * * *(0.034)$ & \\
\hline log (NPL ratio_host) & $0.055(0.042)$ & \\
\hline log (Sovereign yields_orig) & & $-1.402 * * *(0.137)$ \\
\hline log (Sovereign yields_host) & & $-0.456 * * *(0.134)$ \\
\hline avg (log(import)) & $0.381 * * *(0.063)$ & $0.470 * * *(0.085)$ \\
\hline comm_lang & $1.331 * *(0.452)$ & $1.420 * *(0.489)$ \\
\hline $\log ($ distance $)$ & $-0.954 * * *(0.090)$ & $-0.591 * * *(0.103)$ \\
\hline contig & $2.099 * * *(0.425)$ & $1.366 * * *(0.413)$ \\
\hline comrelig & $1.014 * * *(0.271)$ & $0.723 *(0.380)$ \\
\hline colony & $0.491(0.635)$ & $0.956(0.695)$ \\
\hline com_leg_orig & $-0.188(0.188)$ & $0.690 *(0.348)$ \\
\hline corr (GDP) & $0.155(0.203)$ & $0.019(0.254)$ \\
\hline $\log (\operatorname{vol~FX})$ & $-1.173 * * *(0.070)$ & $-0.920 * * *(0.077)$ \\
\hline $\log ($ taxes $)$ & $0.137(0.341)$ & $0.205(0.447)$ \\
\hline Constant & $12.381 * * *(1.457)$ & $11.180 * * *(1.759)$ \\
\hline $\mathrm{N}$ & 9,636 & 6,098 \\
\hline Time FE & Yes & Yes \\
\hline R-squared & 0.385 & 0.478 \\
\hline
\end{tabular}

Notes: $*, * *$, and $* * *$ imply statistical significance at the 10,5 , and 1 percent levels respectively. In the parentheses are reported robust standard errors clustered within country pairs. Yearly time fixed effects are included but unreported. See the 'Data' section for variable description. 
Table 2

Estimation results on the impact of banking and sovereign risk on inward FDI in GIIPS and non-GIIPS EMU countries by OLS.

\begin{tabular}{|c|c|c|c|c|}
\hline \multicolumn{5}{|c|}{ Country Risk } \\
\hline & $\begin{array}{l}\text { Banking Risk } \\
\text { measure }\end{array}$ & $\begin{array}{c}\text { Sovereign } \\
\text { Risk } \\
\text { measure }\end{array}$ & $\begin{array}{c}\text { Banking Risk } \\
\text { measure }\end{array}$ & $\begin{array}{c}\text { Sovereign Risk } \\
\text { measure }\end{array}$ \\
\hline & \multicolumn{2}{|c|}{ non-GIIPS } & \multicolumn{2}{|c|}{ GIIPS } \\
\hline & (1) & (2) & (3) & (4) \\
\hline & $\log (\mathrm{FDI})$ & $\log (\mathrm{FDI})$ & $\log (\mathrm{FDI})$ & $\log (\mathrm{FDI})$ \\
\hline log (NPL ratio_orig) & $-0.175 * * *(0.047)$ & & $-0.160 * *(0.047)$ & \\
\hline $\log$ (NPL ratio_host) & $0.058(0.057)$ & & $0.201(0.601)$ & \\
\hline $\begin{array}{l}\log \text { (Sovereign } \\
\text { yields_orig) }\end{array}$ & & $-1.379 * * *(0.190)$ & & $-1.433 * * *(0.203)$ \\
\hline $\begin{array}{l}\text { log (Sovereign } \\
\text { yields_host) }\end{array}$ & & $-0.413 * *(0.169)$ & & $-0.957 * *(0.257)$ \\
\hline $\operatorname{avg}(\log ($ import $))$ & $0.395 * * *(0.076)$ & $0.494 * * *(0.115)$ & $0.388 * *(0.134)$ & $0.414 * *(0.115)$ \\
\hline comm_lang & $0.927(0.697)$ & $0.831(0.748)$ & $1.542 * *(0.463)$ & $1.239(0.971)$ \\
\hline $\log ($ distance $)$ & $-0.923 * * *(0.109)$ & $-0.513 * * *(0.112)$ & $-1.120 * * *(0.223)$ & $-0.876 * * *(0.188)$ \\
\hline contig & $2.696 * * *(0.392)$ & $2.094 * * *(0.440)$ & $0.787(1.091)$ & $0.187(0.951)$ \\
\hline comrelig & $0.581(0.490)$ & $-0.091(0.557)$ & $1.372 * * *(0.294)$ & $1.060 * *(0.359)$ \\
\hline colony & $0.290(0.893)$ & $0.461(0.978)$ & $0.596(0.450)$ & $1.819 *(0.712)$ \\
\hline com_leg_orig & $-0.308(0.313)$ & $0.446(0.494)$ & $-0.039(0.132)$ & $1.132 * * *(0.159)$ \\
\hline $\operatorname{corr}(\mathrm{GDP})$ & $0.135(0.202)$ & $0.263(0.253)$ & $0.177(0.342)$ & $-0.265(0.233)$ \\
\hline $\log (\operatorname{vol~FX})$ & $-1.130 * * *(0.102)$ & $-0.898 * * *(0.122)$ & $-1.294 * * *(0.080)$ & $-1.016 * * *(0.058)$ \\
\hline $\log ($ taxes $)$ & $0.384(0.466)$ & $0.364(0.623)$ & $-0.490(0.878)$ & $0.585(0.281)$ \\
\hline Constant & $11.459 * * *(1.716$ & $10.023^{* * *}(2.280)$ & $15.322 * * *(3.680)$ & $13.255 * * *(1.709)$ \\
\hline $\mathrm{N}$ & 6,944 & 3,993 & 3,220 & 2,105 \\
\hline Time FE & Yes & Yes & Yes & Yes \\
\hline R-squared & 0.398 & 0.476 & 0.372 & 0.510 \\
\hline
\end{tabular}


Table 3

Robustness check on the impact of banking risk (proxied by RC/RWA) on inward FDI in Euro Area by OLS.

\begin{tabular}{|c|c|}
\hline \multicolumn{2}{|c|}{ Additional banking Risk measure } \\
\hline & $\log (\mathrm{FDI})$ \\
\hline $\log$ (RC/RWA_orig) & $-1.827 * * *(0.283)$ \\
\hline $\log$ (RC/RWA_host) & $0.649(0.387)$ \\
\hline avg (log(import)) & $0.403 * * *(0.062)$ \\
\hline comm_lang & $1.336 * * *(0.450)$ \\
\hline $\log ($ distance $)$ & $-0.975 * * *(0.086)$ \\
\hline contig & $1.987 * * *(0.404)$ \\
\hline comrelig & $0.942 * * *(0.293)$ \\
\hline colony & $0.495(0.616)$ \\
\hline com_leg_orig & $-0.209(0.190)$ \\
\hline $\operatorname{corr}(\mathrm{GDP})$ & $0.039(0.191)$ \\
\hline $\log (\operatorname{vol~FX)}$ & $-1.150 * * *(0.068)$ \\
\hline $\log ($ taxes $)$ & $0.175(0.404)$ \\
\hline Constant & $15.001 * * *(1.833)$ \\
\hline $\mathrm{N}$ & 9,636 \\
\hline Time FE & Yes \\
\hline R-squared & 0.395 \\
\hline
\end{tabular}


Table 4

Estimation results on the impact of foreign investors' hedging incentives and wealth on inward FDI in EMU countries by OLS.

\begin{tabular}{|c|c|c|c|c|}
\hline \multicolumn{5}{|c|}{ Country Risk } \\
\hline & $\begin{array}{c}\text { Banking Risk } \\
\text { measure }\end{array}$ & $\begin{array}{c}\text { Sovereign Risk } \\
\text { measure }\end{array}$ & $\begin{array}{c}\text { Banking Risk } \\
\text { measure }\end{array}$ & $\begin{array}{c}\text { Sovereign Risk } \\
\text { measure }\end{array}$ \\
\hline & \multicolumn{2}{|c|}{ Test for Hedging incentives } & \multicolumn{2}{|c|}{ Test for Origin country Risk Aversion } \\
\hline & (1) & (2) & (3) & (4) \\
\hline & $\log (\mathrm{FDI})$ & $\log (\mathrm{FDI})$ & $\log (\mathrm{FDI})$ & $\log (\mathrm{FDI})$ \\
\hline log (NPL ratio_orig) & $-0.172 * * *(0.037)$ & & $-0.121 * * *(0.029)$ & \\
\hline log (NPL ratio_host) & $0.137(0.083)$ & & $0.044(0.045)$ & \\
\hline log (Sovereign yields_orig) & & $-1.430 * * *(0.152)$ & & $-1.099 * * *(0.124)$ \\
\hline log (Sovereign yields_host) & & $-0.533 * * *(0.162)$ & & $-0.477 * * *(0.133)$ \\
\hline $\operatorname{avg}(\log ($ import $))$ & $0.458 * * *(0.067)$ & $0.501 * * *(0.098)$ & $0.385 * * *(0.063)$ & $0.480 * * *(0.085)$ \\
\hline comm_lang & $1.350 * *(0.492)$ & $1.347 * *(0.548)$ & $1.340 * * *(0.447)$ & $1.411 * * *(0.459)$ \\
\hline $\log ($ distance $)$ & $-0.928 * * *(0.097)$ & $-0.588 * * *(0.121)$ & $-0.845 * * *(0.085)$ & $-0.536 * * *(0.104)$ \\
\hline contig & $2.053 * * *(0.469)$ & $1.148 * *(0.450)$ & $1.989 * * *(0.383)$ & $1.359 * * *(0.392)$ \\
\hline comrelig & $0.932 * * *(0.273)$ & $0.731 *(0.384)$ & $1.040 * * *(0.266)$ & $0.672 *(0.381)$ \\
\hline colony & $0.191(0.668)$ & $0.750(0.749)$ & $0.547(0.569)$ & $0.965(0.641)$ \\
\hline com_leg_orig & $-0.133(0.192)$ & $0.827 * *(0.356)$ & $-0.099(0.170)$ & $0.727 * *(0.327)$ \\
\hline corr (GDP) & $0.079(0.241)$ & $-0.077(0.277)$ & $0.087(0.185)$ & $-0.043(0.240)$ \\
\hline $\log (\operatorname{vol~FX)}$ & $-1.219 * * *(0.070)$ & $-0.952 * * *(0.085)$ & $-0.799 * * *(0.044)$ & $-0.768 * * *(0.072)$ \\
\hline $\log ($ taxes $)$ & $0.146(0.338)$ & $0.224(0.450)$ & $0.100(0.341)$ & $0.208(0.453)$ \\
\hline corr (GDP, MKTCAP) & $-0.444 *(0.218)$ & $-0.332(0.204)$ & & \\
\hline L2 (GDP per capita orig) & & & $0.634 * * *(0.070)$ & $0.504 * * *(0.054)$ \\
\hline Constant & $11.627 * * *(1.795)$ & $11.162 * * *(1.976)$ & $4.315 * *(1.733)$ & $4.959 * *(2.015)$ \\
\hline $\mathrm{N}$ & 8,026 & 5,308 & 9,617 & 6,080 \\
\hline Time FE & Yes & Yes & Yes & Yes \\
\hline R-squared & 0.375 & 0.477 & 0.426 & 0.497 \\
\hline
\end{tabular}

Notes: *,**, and *** imply statistical significance at the 10,5, and 1 percent levels respectively. In the parentheses are reported robust standard errors clustered within country pairs. Yearly time fixed effects are included but unreported. In columns (1) and (2) we proxy hedging incentives using the correlation between host country stock market capitalisation and origin country GDP growth. In columns (3) and (4), defined origin country wealth using the second lag of GDP per capita of origin countries and assuming that wealth is positively associated to risk-taking. 
Table 5

Results on the impact of 'push' and 'pull' risk factors on inward FDI in the EMU by two-stage OLS regression.

\begin{tabular}{|c|c|c|c|c|}
\hline \multicolumn{5}{|c|}{ Country Risk } \\
\hline & Banking Risk & Sovereign Risk & Banking Risk & Sovereign Risk \\
\hline & \multicolumn{2}{|c|}{ VIX } & \multicolumn{2}{|c|}{ WUI } \\
\hline & (1) & $(2)$ & (3) & (4) \\
\hline & $\log (\mathrm{FDI})$ & $\log (\mathrm{FDI})$ & $\log (\mathrm{FDI})$ & $\log (\mathrm{FDI})$ \\
\hline $\log$ (NPL ratio_orig) & $-0.162 * * *(0.043)$ & & $-0.116 * * *(0.036)$ & \\
\hline log (NPL ratio_host) & $0.057(0.044)$ & & $0.056(0.039)$ & \\
\hline $\log$ (Sovereign yields_orig) & & $-1.334 * * *(0.107)$ & & $-0.701 * * *(0.102)$ \\
\hline $\log$ (Sovereign yields_host) & & $-0.300 * * *(0.112)$ & & $-0.148 *(0.086)$ \\
\hline res_VIX & $0.065(0.149)$ & $3.035 * * *(0.435)$ & & \\
\hline res_WUI & & & $0.144(0.112)$ & $-1.395 * * *(0.332)$ \\
\hline $\operatorname{avg}(\log ($ import $))$ & $0.381 * * *(0.040)$ & $0.470 * * *(0.047)$ & $0.428 * * *(0.020)$ & $0.484 * * *(0.032)$ \\
\hline comm_lang & $1.331 * * *(0.411)$ & $1.420 * * *(0.435)$ & $1.453 * * *(0.369)$ & $1.796 * * *(0.378)$ \\
\hline $\log ($ distance $)$ & $-0.954 * * *(0.099)$ & $-0.591 * * *(0.114)$ & $-0.445 * * *(0.091)$ & $-0.305 * * *(0.109)$ \\
\hline contig & $2.099 * * *(0.411)$ & $1.366 * * *(0.415)$ & $1.504 * * *(0.374)$ & $0.732 *(0.385)$ \\
\hline comrelig & $1.014 * * *(0.293)$ & $0.723 * *(0.361)$ & $0.881 * * *(0.256)$ & $0.598 *(0.333)$ \\
\hline colony & $0.491(0.524)$ & $0.956 *(0.576)$ & $-0.118(0.474)$ & $0.186(0.521)$ \\
\hline com_leg_orig & $-0.188(0.180)$ & $0.690 * * *(0.231)$ & $-0.404 * *(0.159)$ & $0.289(0.224)$ \\
\hline corr (GDP) & $0.155(0.139)$ & $0.019(0.178)$ & $0.254 * *(0.125)$ & $0.143(0.167)$ \\
\hline $\log ($ vol FX) & $-1.173 * * *(0.078)$ & $-0.920 * * *(0.097)$ & $-0.804 * * *(0.067)$ & $-0.691 * * *(0.091)$ \\
\hline $\log$ (taxes) & $0.137(0.370)$ & $0.205(0.425)$ & $0.275(0.318)$ & $0.197(0.393)$ \\
\hline Constant & $12.326 * * *(1.514)$ & $8.833 * * *(1.640)$ & $6.240 * * *(1.353)$ & $5.503 * * *(1.589)$ \\
\hline $\mathrm{N}$ & 9,636 & 6,098 & 9,406 & 5,911 \\
\hline Time FE & Yes & Yes & Yes & Yes \\
\hline R-squared & 0.440 & 0.494 & 0.496 & 0.535 \\
\hline
\end{tabular}

Notes: *,**, and *** imply statistical significance at the 10,5, and 1 percent levels respectively. In the parentheses are reported robust standard errors clustered within country pairs. Yearly time fixed effects are included but unreported. In columns (1) and (2) we report the results of a two-stage OLS regression having the VIX as of 'push' risk factor. In columns (3) and (4) we report the results of a two-stage OLS regression using the World Uncertainty Index (WUI) as of 'push' risk factor. In Table 5, we disclose only the results of the second stage regression. 
Table 6

Estimation results on the impact of banking and sovereign risk on inward FDI in the EMU by OLS.

\begin{tabular}{|c|c|c|c|}
\hline & Banking Risk & Sovereign Risk & Both \\
\hline & (1) & (2) & (3) \\
\hline & $\log (\mathrm{FDI})$ & $\log (\mathrm{FDI})$ & $\log (\mathrm{FDI})$ \\
\hline log (Diff_bank_risk) & $-0.148 * * *(0.036)$ & & $-0.088^{* *}(0.044)$ \\
\hline log (Diff_sov_risk) & & $-1.145 * * *(0.097)$ & $-1.116 * * *(0.097)$ \\
\hline avg (log(import)) & $0.697 * * *(0.236)$ & $-0.203(0.309)$ & $-0.266(0.308)$ \\
\hline comm_lang & $1.255 * * *(0.428)$ & $1.238 * * *(0.461)$ & $1.209 * * *(0.463)$ \\
\hline $\log ($ distance $)$ & $-0.947 * * *(0.098)$ & $-0.579 * * *(0.113)$ & $-0.622 * * *(0.114)$ \\
\hline contig & $2.182 * * *(0.408)$ & $1.558 * * *(0.418)$ & $1.534 * * *(0.418)$ \\
\hline comrelig & $0.980 * * *(0.307)$ & $0.597 *(0.357)$ & $0.600 *(0.358)$ \\
\hline colony & $0.584(0.520)$ & $1.042 *(0.591)$ & $1.030 *(0.597)$ \\
\hline com_leg_orig & $-0.205(0.190)$ & $0.629 * * *(0.231)$ & $0.655 * * *(0.232)$ \\
\hline corr (GDP) & $0.081(0.157)$ & $0.062(0.182)$ & $0.056(0.182)$ \\
\hline $\log (\operatorname{vol~FX)}$ & $-1.180 * * *(0.078)$ & $-1.025 * * *(0.094)$ & $-1.024 * * *(0.094)$ \\
\hline $\log ($ taxes $)$ & $1.028 * *(0.497)$ & $-0.773(0.757)$ & $-0.925(0.754)$ \\
\hline Constant & $7.772 * * *(2.475)$ & $14.964 * * *(3.530)$ & $16.124 * * *(3.524)$ \\
\hline $\mathrm{N}$ & 9,636 & 6,098 & 6,098 \\
\hline Time FE & Yes & Yes & Yes \\
\hline Host FE & Yes & Yes & Yes \\
\hline R-squared & 0.399 & 0.484 & 0.486 \\
\hline
\end{tabular}

Notes: $*, * *$, and $* * *$ imply statistical significance at the 10,5 , and 1 percent levels respectively. In the parentheses are reported robust standard errors clustered within country pairs. Yearly time fixed effects and host country fixed effects are included but unreported. See the 'Robustness' section for variable description. 


\section{Figures}

\section{Figure 1}

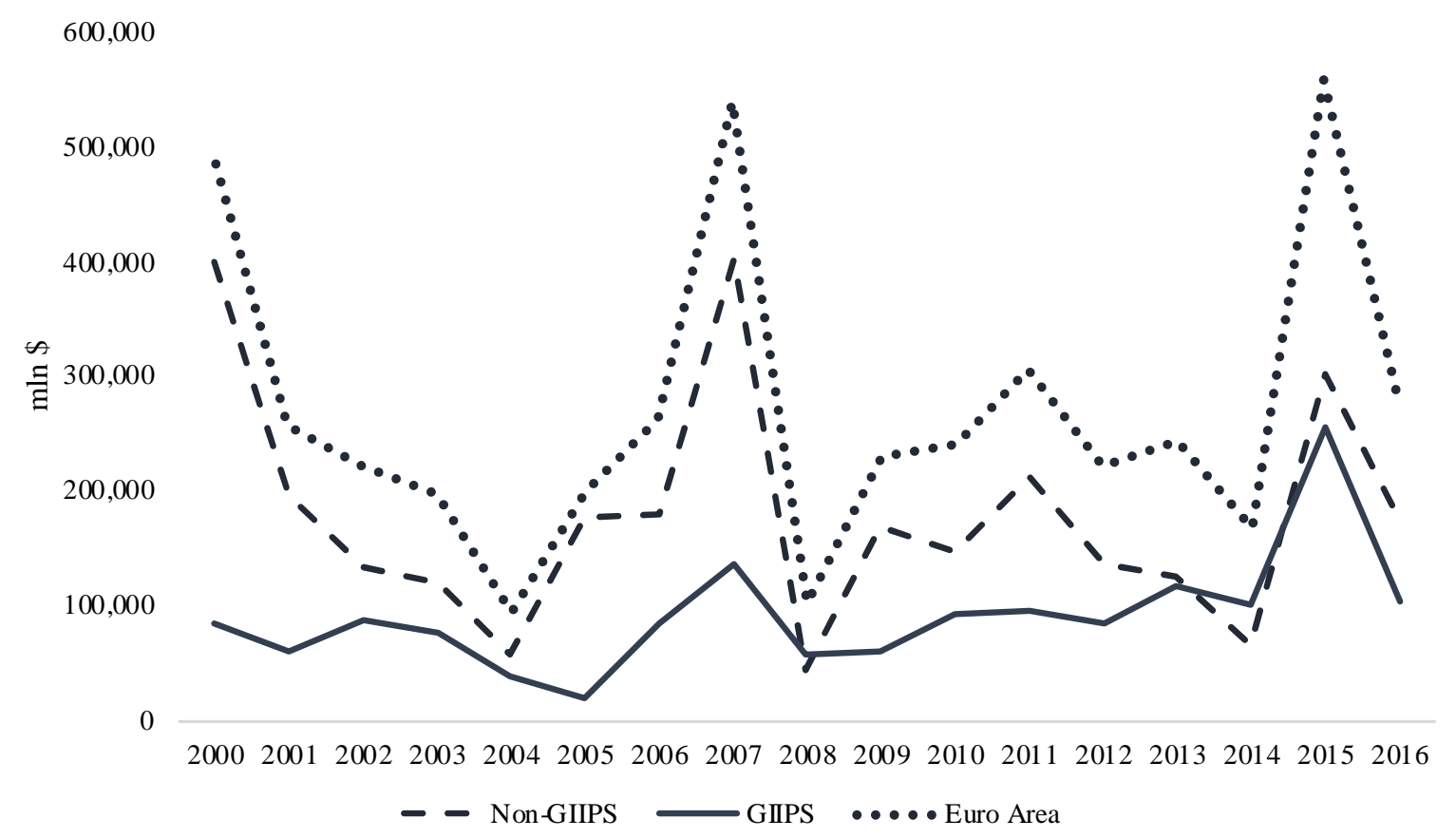

Notes. In this Figure, we display FDI inflows in the Euro Area (dotted line), as well as in GIIPS (solid line) and Non-GIIPS (dashed line) countries. FDI inflow data ranges from 2002 to 2016 and its reported at current prices in million USD.

Source. UNCAD 


\section{Figure 2}
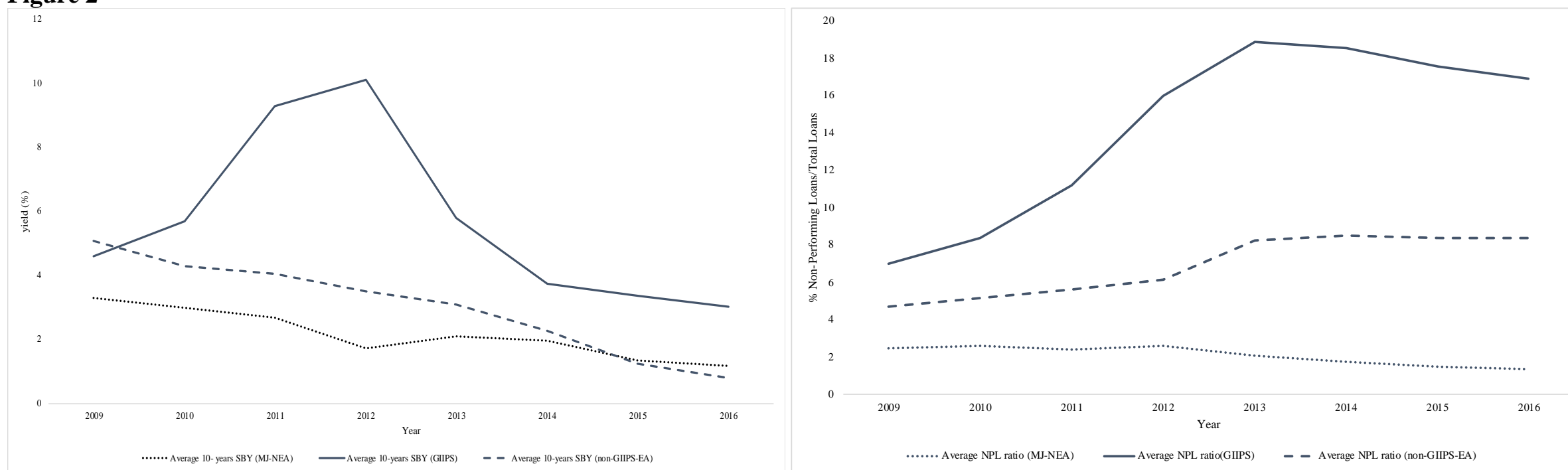

Notes. On the left-hand side, we present the average 10-year Sovereign Bond Yields. In our paper, we use this indicator to measure EA sovereign risk. On the right-hand side, we show instead Non-Performing Loans/Total Gross Loans. In our paper, we use this indicator to measure the risk of the EA banking sector. Both measures have been averaged across three main groups of countries: major non-EA countries \{USA, UK, CAN, JPN\} (MJ-NEA), Euro Area Periphery (GIIPS) and non-Periphery EA countries (non-GIIPS-EA). For a detailed list of the countries included in each of the aforementioned categories, see Table 7. Source. IMF International Financial Statistics (IMF IFS), OECD Financial Statistics, CEIC, Oesterreichische Nationalbank, Bloomberg, World Bank Global Financial Development DataBank. 
Figure 3

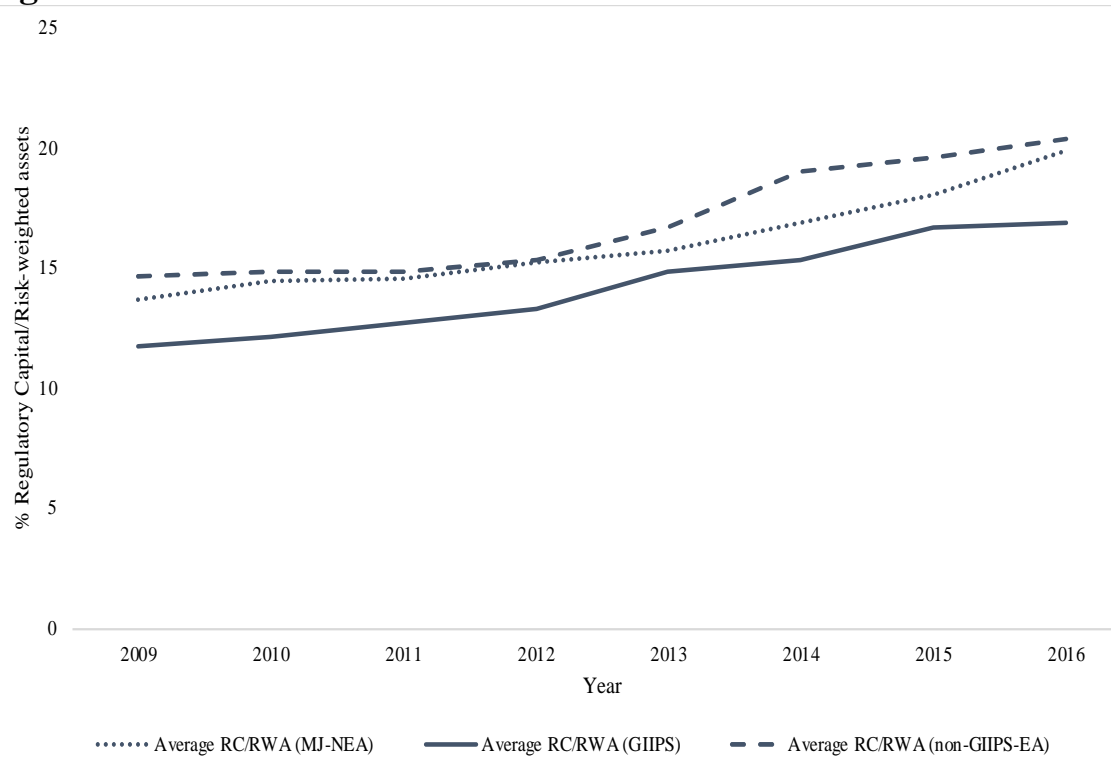

Notes. Averages of Regulatory Capital/Risk-Weighted Assets of major non-EA countries \{USA, UK, CAN, JPN\} (MJ-NEA), Euro Area Periphery (GIIPS) and non-Periphery EA countries (non-GIIPS-EA). In our paper, we use this indicator to measure the risk of the EA banking sector. For a detailed list of the countries included in each of the aforementioned categories, see Table 7.

Source. WorldBank 


\section{Appendix}

\section{A.0 A: Dataset Description}

\section{A.0.1 Data}

Inward FDI: Annual data on foreign countries' FDI holdings in EA countries is collected from the IMF Coordinated Direct Investment Survey (CDIS). From this dataset, we collected 'inward' FDI positions in EA countries, cross-classified by economy of the immediate investor (see IMF's Coordinated Direct Investment Survey Guide - 2015).

Gravity Variables: Gravity variables of 'Geographical Distance', 'Common Official Language', 'Contiguity', 'Common Religion', 'Colony', 'Time difference' and 'Common Legal Origin' are instead collected from the 'Comptes Harmonisés sur les Echanges et L'Economie Mondiale (CHELEM)' database, developed by the CEPII Research Center. The 'Gravity Dataset' is a dyadic dataset, disclosing many features for the reported country pairs, such as: geographical distance (in kilometres) between the capitals of most of the countries in the world, whether or not the countries share the same official language, whether the countries share a geographical border, whether the countries share the same official religion or colonization history, the time difference between the countries, their legal origin and more (see Meyer and Zignago, 2011).

Country Risk Variables: Country Risk variables have been gathered the World Bank Global Financial Development Database and from IMF Financial Soundness Indicators Database (with the exception of the 10-year Sovereign Bond Yields, for which we used IMF IFS, supplemented for a few missing observations with OECD Financial Statistics, Oesterreichische NationalBank, CEIC and Bloomberg). The World Bank Global Financial Development Database is an extensive dataset gathering information on the functioning of the financial 
system. Among the information presented in this database, it reports statistics on: financial depth, financial services access, efficiency and stability (resilience) of the financial system and of the institutions operating in it. Almost all our 'Country Risk' variables have been collected from the Financial Stability Section of this database. Additionally, the IMF Financial Soundness Indicators Database is also a comprehensive dataset providing statistics on financial system resilience. In particular, it contains granular information on: financial intermediaries' stability, as well as detailed statistics on other entities such as financial and non-financial corporations. From the latter database, we collected data on banks' regulatory capital to riskweighted assets, that we then further supplemented using the World Bank Global Financial Development Database.

GDP per capita and GDP Growth: Annual data on GDP per capital has been obtained from World Bank Statistics. This database combines macro-economic data from the World Bank National Account database and from the OECD National Accounts data files.

Average host country imports: Annual bilateral import of Euro Area countries (host) from origin countries have been collected from the International Monetary Fund, Direction of Trade Statistics. This data has been then used to compute the average between 2009 and 2016.

Foreign Exchange rate and Foreign Exchange volatility: Bilateral exchange rate of all origin countries national currencies against the euro, have been collected from S\&P Global Database. In the case of Euro Area countries, we reported the value of the Euro defined in terms of the SDR. The SDR is an international reserve asset, created by the IMF in 1969 to supplement its member countries' official reserves, whose value is determined in terms of a basket of five major currencies (U.S. dollar, the euro, the Chinese renminbi, the Japanese yen, 
and the British pound sterling). Data for the SDR have been collected from the IMF Exchange rate data.

Taxes: Annual data on domestic government tax revenues as a percentage of GDP are collected from World Bank Global Financial Development Database.

\section{A.0.2 - Countries}

In our analysis we included a broad range of countries (i.e., 112 countries). The countries that we considered are all those voluntarily participating in the IMF Coordinated Direct Investment Survey (CDIS), with the exception of tax heavens, small countries with large financial centres or war zones. Specifically, below we report the detailed composition of our dataset:

Countries included in the dataset: Within the Euro Area (EA), we considered all countries with the exception of Lithuania, as it joined the EA in 2015, Malta and Luxembourg. With respect to non-Euro Area countries, we consider: Albania, Algeria, Angola, Argentina, Armenia, Australia, Bangladesh, Belarus, Bolivia, Bosnia and Herzegovina, Botswana, Brazil, Brunei Darussalam, Bulgaria, Cabo Verde, Cameroon, Cambodia, Canada, Central African Republic, Chile, China, P.R. Mainland, Colombia, Congo, Republic of Cote d'Ivoire, Croatia, Czech Republic, Denmark, Dominica, Egypt, El Salvador, Gabon, Georgia, Ghana, Guatemala, Guinea, Guinea- Bissau, Guyana, Hungary, Iceland, India, Indonesia, Iran, Islamic Republic of, Israel, Japan, Jordan, Kazakhstan, Kenya, Korea, Republic of Kuwait, Kyrgyz Republic, Lao People's Democratic Republic, Liberia, Lithuania, Macedonia, FYR, Madagascar, Malawi, Malaysia, Mali, Mauritania, Mexico, Mongolia, Morocco, Mozambique, Namibia, New Zealand, Niger, Norway, Oman, Pakistan, Papua New Guinea, Paraguay, Peru, Philippines, Poland, Qatar, Russian Federation, Rwanda, Saudi Arabia, South Africa, Sri 
Lanka, Sudan, Swaziland, Sweden, Tanzania, Thailand, Turkey, Uganda, Ukraine, United

Arab Emirates, United Kingdom, United States, Uruguay, Venezuela, Republica Bolivariana de, Vietnam, Yemen, Republic of Zambia, Zimbabwe.

\section{A.0.3 - Descriptive Statistics}

Table 7

Summary statistics on foreign direct investment and key independent variables.

\begin{tabular}{|c|c|c|c|c|c|c|}
\hline \multicolumn{7}{|c|}{ Panel A: EA inward direct investment ( $\mathrm{mln} \$$ ) } \\
\hline GIIPS & $\begin{array}{c}\text { Country } \\
\text { Code }\end{array}$ & $\mathbf{N}$ & Mean & Std Dev & Min & Max \\
\hline Greece & GRC & 115 & 405.877 & $1,085.274$ & $-1,633.905$ & $5,358.714$ \\
\hline Ireland & IRL & 120 & $10,968.990$ & $36,481.940$ & $-23,034.350$ & $154,667.400$ \\
\hline Italy & ITA & 120 & $17,134.910$ & $27,606.310$ & 7.640 & $124,198.700$ \\
\hline Portugal & PRT & 120 & $1,563.345$ & $4,669.577$ & $-8,047.017$ & $24,486.880$ \\
\hline Spain & ESP & 120 & $6,962.184$ & $10,769.410$ & $-13,549.280$ & $38,622.490$ \\
\hline $\begin{array}{c}\text { Non-GIIPS } \\
\text { EA }\end{array}$ & $\begin{array}{c}\text { Country } \\
\text { Code }\end{array}$ & $\mathbf{N}$ & Mean & Std Dev & Min & Max \\
\hline Austria & AUT & 120 & $5,389.935$ & $8,987.756$ & -841.423 & $35,873.030$ \\
\hline Belgium & BEL & 120 & $20,817.410$ & $46,705.070$ & $-3,770.425$ & $225,544.700$ \\
\hline Cyprus & CYP & 119 & $2,095.746$ & $5,230.197$ & $-5,192.275$ & $27,625.580$ \\
\hline Estonia & EST & 120 & 85.241 & 281.451 & -76.971 & $1,962.515$ \\
\hline Finland & FIN & 120 & $3,085.604$ & $6,469.908$ & $-1,011.345$ & $31,934.490$ \\
\hline France & FRA & 120 & $34,176.300$ & $50,160.460$ & 45.023 & $178,235.400$ \\
\hline Germany & DEU & 120 & $27,228.140$ & $47,179.820$ & 87.096 & $242,784.100$ \\
\hline Latvia & LVA & 119 & 41.694 & 112.753 & -40.353 & 649.823 \\
\hline Netherlands & NLD & 120 & $55,631.900$ & $64,693.200$ & 0.000 & $248,562.200$ \\
\hline $\begin{array}{c}\text { Slovak } \\
\text { Republic }\end{array}$ & SVK & 120 & 79.657 & 383.796 & -602.303 & $2,907.801$ \\
\hline Slovenia & SVN & 114 & 13.949 & 116.841 & -246.902 & $1,140.897$ \\
\hline \multicolumn{7}{|c|}{ Panel B: 10-years Sovereign Bonds Yields (\%) } \\
\hline GIIPS & $\begin{array}{c}\text { Country } \\
\text { Code }\end{array}$ & $\mathbf{N}$ & Mean & Std Dev & Min & Max \\
\hline Greece & GRC & 120 & 10.959 & 5.244 & 5.174 & 22.498 \\
\hline Ireland & IRL & 120 & 4.352 & 2.771 & 0.736 & 9.602 \\
\hline Italy & ITA & 120 & 3.710 & 1.444 & 1.488 & 5.493 \\
\hline Portugal & PRT & 120 & 5.755 & 2.921 & 2.423 & 10.548 \\
\hline Spain & ESP & 120 & 3.741 & 1.542 & 1.393 & 5.845 \\
\hline $\begin{array}{c}\text { Non-GIIPS } \\
\text { EA }\end{array}$ & $\begin{array}{c}\text { Country } \\
\text { Code }\end{array}$ & $\mathbf{N}$ & Mean & Std Dev & Min & Max \\
\hline Austria & AUT & 120 & 2.184 & 1.195 & 0.377 & 3.937 \\
\hline Belgium & BEL & 120 & 2.505 & 1.311 & 0.476 & 4.233 \\
\hline Cyprus & CYP & 120 & 5.350 & 1.061 & 3.773 & 7.000 \\
\hline Estonia & EST & 30 & 6.873 & 0.920 & 5.968 & 7.778 \\
\hline Finland & FIN & 120 & 2.005 & 1.106 & 0.363 & 3.739 \\
\hline France & FRA & 120 & 2.226 & 1.090 & 0.467 & 3.649 \\
\hline Germany & DEU & 120 & 1.673 & 1.042 & 0.090 & 3.223 \\
\hline Latvia & LVA & 120 & 5.064 & 4.029 & 0.534 & 12.358 \\
\hline
\end{tabular}




\begin{tabular}{|c|c|c|c|c|c|c|}
\hline Netherlands & NLD & 120 & 2.000 & 1.108 & 0.292 & 3.687 \\
\hline $\begin{array}{c}\text { Slovak } \\
\text { Republic }\end{array}$ & SVK & 120 & 3.029 & 1.567 & 0.543 & 4.707 \\
\hline Slovenia & SVN & 120 & 3.865 & 1.644 & 1.149 & 5.812 \\
\hline \multicolumn{7}{|c|}{ Panel C: Non-Performing Loans/Total Gross Loans } \\
\hline GIIPS & $\begin{array}{c}\text { Country } \\
\text { Code }\end{array}$ & $\mathbf{N}$ & Mean & Std Dev & Min & Max \\
\hline Greece & GRC & 120 & 24.055 & 11.623 & 7.000 & 36.647 \\
\hline Ireland & IRL & 120 & 17.357 & 5.453 & 9.800 & 25.709 \\
\hline Italy & ITA & 120 & 14.334 & 3.371 & 9.400 & 18.064 \\
\hline Portugal & PRT & 120 & 9.325 & 2.821 & 4.800 & 11.962 \\
\hline Spain & ESP & 120 & 6.486 & 1.714 & 4.100 & 9.381 \\
\hline $\begin{array}{c}\text { Non-GIIPS } \\
\text { EA }\end{array}$ & $\begin{array}{c}\text { Country } \\
\text { Code }\end{array}$ & $\mathbf{N}$ & Mean & Std Dev & Min & Max \\
\hline Austria & AUT & 120 & 2.885 & 0.359 & 2.300 & 3.473 \\
\hline Belgium & BEL & 120 & 3.578 & 0.476 & 2.799 & 4.245 \\
\hline Cyprus & CYP & 120 & 27.329 & 18.361 & 4.500 & 48.676 \\
\hline Estonia & EST & 120 & 2.745 & 1.766 & 0.870 & 5.375 \\
\hline Finland & FIN & 60 & 0.550 & 0.050 & 0.500 & 0.600 \\
\hline France & FRA & 120 & 4.112 & 0.227 & 3.759 & 4.495 \\
\hline Germany & DEU & 105 & 2.773 & 0.442 & 1.980 & 3.300 \\
\hline Latvia & LVA & 120 & 9.039 & 4.703 & 3.652 & 15.934 \\
\hline Netherlands & NLD & 120 & 2.912 & 0.239 & 2.531 & 3.227 \\
\hline $\begin{array}{c}\text { Slovak } \\
\text { Republic }\end{array}$ & SVK & 120 & 5.222 & 0.403 & 4.444 & 5.836 \\
\hline Slovenia & SVN & 120 & 10.136 & 3.351 & 5.071 & 15.180 \\
\hline \multicolumn{7}{|c|}{ Panel D: EA Regulatory Capital/Risk-Weighted Assets } \\
\hline GIIPS & $\begin{array}{c}\text { Country } \\
\text { Code }\end{array}$ & $\mathbf{N}$ & Mean & Std Dev & Min & Max \\
\hline Greece & GRC & 120 & 13.108 & 2.527 & 9.569 & 16.947 \\
\hline Ireland & IRL & 120 & 19.988 & 4.480 & 12.780 & 26.941 \\
\hline Italy & ITA & 120 & 13.295 & 1.018 & 11.650 & 14.789 \\
\hline Portugal & PRT & 120 & 11.807 & 1.308 & 9.780 & 13.327 \\
\hline Spain & ESP & 120 & 13.031 & 1.198 & 11.586 & 14.849 \\
\hline $\begin{array}{c}\text { Non-GIIPS } \\
\text { EA }\end{array}$ & $\begin{array}{c}\text { Country } \\
\text { Code }\end{array}$ & $\mathbf{N}$ & Mean & Std Dev & Min & Max \\
\hline Austria & AUT & 120 & 16.500 & 1.027 & 15.026 & 17.976 \\
\hline Belgium & BEL & 120 & 18.389 & 0.637 & 17.262 & 19.305 \\
\hline Cyprus & CYP & 120 & 13.351 & 2.908 & 7.343 & 16.943 \\
\hline Estonia & EST & 120 & 24.721 & 5.969 & 18.607 & 35.653 \\
\hline Finland & FIN & 120 & 17.455 & 3.463 & 14.188 & 23.337 \\
\hline France & FRA & 120 & 14.804 & 2.054 & 12.324 & 17.752 \\
\hline Germany & DEU & 120 & 17.423 & 1.413 & 14.820 & 19.160 \\
\hline Latvia & LVA & 120 & 17.578 & 2.736 & 13.724 & 21.823 \\
\hline Netherlands & NLD & 120 & 16.481 & 3.091 & 13.478 & 22.375 \\
\hline $\begin{array}{c}\text { Slovak } \\
\text { Republic }\end{array}$ & SVK & 120 & 15.501 & 2.142 & 12.571 & 17.982 \\
\hline Slovenia & SVN & 120 & 14.458 & 3.294 & 11.320 & 19.155 \\
\hline
\end{tabular}

Notes: Panel A discloses descriptive statistics on inward FDI stock received by EA countries between 2009 and 2016. Panel B contains descriptive statistics on 10-year sovereign bond yields of EA countries. In Panel $\mathrm{C}$ we report descriptive statistics EA banks NPL ratio. Panel D shows descriptive statistics on Regulatory Capital held by EA banks as a portion of their Risk-Weighted assets. For all the Panels, we report statistics on GIIPS and non-GIIPS EA countries separately. 


\section{A.1 Additional analyses}

\section{A.1.2 Correlation matrix}

Table 8. Correlation Matrix

\begin{tabular}{|c|c|c|c|c|c|c|c|c|c|c|}
\hline & 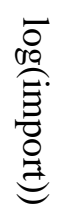 & 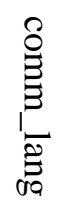 & 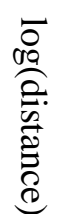 & $\underset{\infty}{\stackrel{8}{\rightleftarrows}}$. & & $\stackrel{8}{\stackrel{0}{\varrho}}$ & 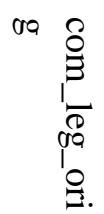 & 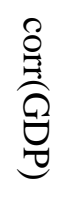 & 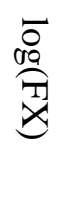 & 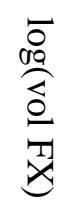 \\
\hline 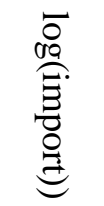 & - & & & & & & & & & \\
\hline 畺 & $\begin{array}{l}\dot{b} \\
\dot{\omega} \\
\dot{\omega}\end{array}$ & - & & & & & & & & \\
\hline 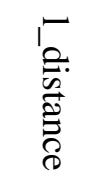 & $\stackrel{0}{8}$ & $\dot{\dot{\theta}}$ & - & & & & & & & \\
\hline$\underset{\infty}{\stackrel{8}{g}}$ & $\stackrel{\stackrel{\theta}{\theta}}{\theta}$ & $\stackrel{\theta}{8}$ & $\underset{\dot{d}}{\dot{d}}$ & - & & & & & & \\
\hline$\underset{\substack{0 \\
\stackrel{0}{0}}}{\stackrel{8}{0}}$ & $\stackrel{\ominus}{\dot{\omega}_{\omega}^{\prime}}$ & $\stackrel{\ominus}{\tilde{N}}$ & $\stackrel{\dot{\theta}}{\circ}$ & $\stackrel{\circ}{\circ}$ & - & & & & & \\
\hline$\frac{\delta}{\stackrel{0}{g}}$ & 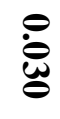 & 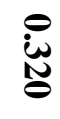 & $\stackrel{\dot{\theta}}{8}$ & 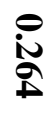 & $\stackrel{\theta}{\vec{a}}$ & - & & & & \\
\hline 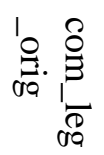 & $\stackrel{\dot{\phi}}{\dot{\phi}}$ & $\stackrel{\dot{N}}{\infty}$ & $\stackrel{\dot{\theta}}{\dot{\phi}}$ & $\stackrel{\ominus}{\dot{V}}$ & $\dot{\theta}$ & 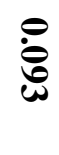 & - & & & \\
\hline$\stackrel{\overbrace{}}{\overparen{B}}$ & $\stackrel{\ominus}{\dot{N}}$ & $\dot{\dot{\sigma}}$ & 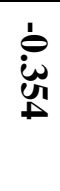 & $\stackrel{\sim}{\sim}$ & $\stackrel{\theta}{\dot{\theta}}$ & $\begin{array}{l}\circ \\
\stackrel{0}{0}\end{array}$ & $\stackrel{\circ}{\mathscr{\varphi}}$ & - & & \\
\hline 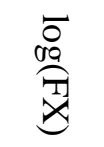 & $\stackrel{\circ}{8}$ & 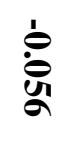 & î & $\stackrel{\dot{\theta}}{\text { อे }}$ & $\dot{i ্ d}_{\infty}^{\infty}$ & $\begin{array}{l}\dot{0} \\
0 \\
0\end{array}$ & 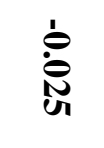 & $\dot{\mathscr{\theta}}$ & - & \\
\hline 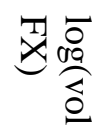 & $\begin{array}{l}0 \\
8 \\
8\end{array}$ & $\dot{\dot{\theta}}$ & $\underset{\dot{\phi}}{\stackrel{0}{0}}$ & 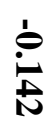 & $\underset{\text { de }}{\stackrel{\dot{\theta}}{\theta}}$ & : & $\stackrel{\dot{\theta}}{\sharp}$ & i & $\ddot{\dot{u}_{n}}$ & - \\
\hline
\end{tabular}


Table 8 Continued. Transposed

\begin{tabular}{|c|c|c|c|c|c|c|}
\hline & $\log ($ taxes $)$ & $\log (10$ SBY)orig & $\log (10$ SBY)host & $\log (\mathrm{RCRWA})$ orig & $\log (\mathrm{RCRWA})$ host & $\log ($ NPL)orig \\
\hline $\log ($ import $))$ & -0.239 & 0.006 & -0.273 & 0.014 & -0.051 & -0.008 \\
\hline comm_lang & 0.027 & -0.02 & -0.009 & 0.003 & 0.101 & -0.013 \\
\hline $\log ($ distance $)$ & 0.012 & 0.322 & 0.043 & -0.045 & -0.043 & -0.22 \\
\hline contig & -0.05 & -0.137 & -0.053 & -0.019 & 0.029 & 0.075 \\
\hline comrelig & -0.054 & -0.078 & -0.091 & -0.006 & 0.0181 & 0.046 \\
\hline colony & -0.045 & 0.008 & -0.012 & -0.021 & -0.022 & 0.004 \\
\hline com_leg_orig & 0.058 & 0.062 & 0.082 & -0.051 & -0.043 & 0.076 \\
\hline corr (GDP) & -0.086 & -0.168 & -0.191 & -0.011 & 0.156 & 0.052 \\
\hline $\log (\mathrm{FX})$ & 0.008 & 0.263 & -0.036 & 0.221 & 0.027 & 0.009 \\
\hline $\log ($ vol FX) & 0.007 & 0.501 & -0.013 & 0.123 & 0.013 & -0.026 \\
\hline $\log ($ taxes $)$ & 1 & -0.035 & 0.13 & 0.027 & 0.0627 & -0.018 \\
\hline $\log (10 \mathrm{SBY})$-orig & & 1 & 0.195 & -0.007 & -0.151 & 0.148 \\
\hline $\log (10 \mathrm{SBY})$ host & & & 1 & -0.164 & -0.596 & 0.101 \\
\hline $\log (\mathrm{RCRWA})$-orig & & & & 1 & 0.111 & -0.095 \\
\hline $\log ($ RCRWA)_host & & & & & 1 & -0.074 \\
\hline $\log (\mathrm{NPL})$ orig & & & & & & 1 \\
\hline
\end{tabular}

Notes: All the coefficients reported in bold are significant at 5\% level.

\section{A.1.3 Additional tests}

As additional tests, we performed: (i) Wooldridge test for serial correlation, (ii) Pesaran test for cross-sectional dependence and (iii) Fisher test on variable stationarity. As a result of evidence of serial correlation and cross-sectional dependence, we corrected our standard error structure using time fixed-effects and clustering of our standard errors at the host country level. 


\section{A.2 Additional test results}

In this section, we present the results of other tests that we perform to robustify the validity of

our theory.

Table 9

Estimation results on the impact of banking and sovereign risk on inward FDI in the EMU, accounting for origin countries' economic growth. Regression results obtained by OLS.

\section{Country Risk}

Banking Risk measure

$\log$ (NPL ratio_orig)

$\log$ (NPL ratio_host)

$\log$ (Sovereign yields_orig)

$\log$ (Sovereign yields_host)

avg (log(import))

comm_lang

$\log$ (distance)

contig

comrelig

colony

com_leg_orig

corr (GDP)

$\log ($ vol FX)

$\log$ (taxes)

L1 (GDP Growth_orig)

Constant

$\mathrm{N}$

Time FE

R-squared

(1) \\ (1)}

$\log$ (FDI)

$-0.178 * * *(0.038)$

$0.065(0.047)$

$0.353 * * *(0.060)$

$1.180 * *(0.425)$

$-0.992 * * *(0.102)$

$2.411 * * *(0.341)$

$0.938 * * *(0.308)$

$0.357(0.683)$

$-0.251(0.231)$

$-0.045(0.218)$

$-1.178 * * *(0.081)$

$0.176(0.313)$

$0.042(0.043)$

$12.845 * * *(1.462)$
Sovereign Risk measure

(2)

$\log (\mathrm{FDI})$

$-1.449 * * *(0.157)$

$-0.443 * * *(0.149)$

$0.431 * * *(0.083)$

$1.133 * *(0.466)$

$-0.562 * * *(0.104)$

$1.669 * * *(0.368)$

$0.704(0.427)$

$0.595(0.765)$

$0.623(0.395)$

$-0.079(0.300)$

$-0.936 * * *(0.087)$

$0.186(0.426)$

$0.064(0.045)$

$11.309 * * *(1.759)$

Notes: *,**, and *** imply statistical significance at the 10,5, and 1 percent levels respectively. In the parentheses are reported robust standard errors clustered within country pairs. Yearly time fixed effects are included but unreported. As proxy for economic growth, in this Table we adopt the first lag of GDP growth of origin countries; other variables are described in the 'Data' section. 
Table 10

Estimation results on the impact of banking and sovereign risk on inward FDI in the EMU, accounting for origin countries' financial sophistication ${ }^{10}$. Regression results obtained by OLS.

\begin{tabular}{|c|c|c|}
\hline \multicolumn{3}{|c|}{ Country Risk } \\
\hline & Banking Risk measure & $\begin{array}{c}\text { Sovereign Risk } \\
\text { measure }\end{array}$ \\
\hline & $(1)$ & (2) \\
\hline & $\log (\mathrm{FDI})$ & $\log (\mathrm{FDI})$ \\
\hline log (NPL ratio_orig) & $-0.224 * * *(0.036)$ & \\
\hline log (NPL ratio_host) & $0.040(0.043)$ & \\
\hline $\begin{array}{l}\log \text { (Sovereign } \\
\text { yields_orig) }\end{array}$ & & $-1.168 * * *(0.151)$ \\
\hline $\begin{array}{l}\log \text { (Sovereign } \\
\text { yields_host) }\end{array}$ & & $-0.483 * *(0.174)$ \\
\hline $\operatorname{avg}(\log ($ import $))$ & $0.384 * * *(0.062)$ & $0.561 * * *(0.097)$ \\
\hline comm_lang & $1.418 * * *(0.438)$ & $1.192 *(0.617)$ \\
\hline $\log ($ distance $)$ & $-1.118 * * *(0.087)$ & $-1.085 * * *(0.106)$ \\
\hline contig & $1.507 * * *(0.390)$ & $0.412(0.447)$ \\
\hline comrelig & $1.003 * * *(0.284)$ & $0.597(0.450)$ \\
\hline colony & $0.494(0.619)$ & $0.740(0.617)$ \\
\hline com_leg_orig & $-0.131(0.171)$ & $0.504 *(0.271)$ \\
\hline corr (GDP) & $0.117(0.176)$ & $0.044(0.292)$ \\
\hline $\log (\operatorname{vol~FX})$ & $-1.008 * * *(0.051)$ & $-0.879 * * *(0.089)$ \\
\hline $\log (\operatorname{taxes})$ & $0.120(0.341)$ & $0.088(0.510)$ \\
\hline $\log (\mathrm{MKTCAP} / \mathrm{GDP}$ orig) & $0.346^{* * *}(0.042)$ & $0.927 * * *(0.125)$ \\
\hline Constant & $12.659 * * *(1.411)$ & $11.436 * * *(1.850)$ \\
\hline $\mathrm{N}$ & 9,636 & 6,098 \\
\hline Time FE & Yes & Yes \\
\hline R-squared & 0.440 & 0.494 \\
\hline
\end{tabular}

Notes: $*, * *$, and $* * *$ imply statistical significance at the 10,5 , and 1 percent levels respectively. In the parentheses are reported robust standard errors clustered within country pairs. Yearly time fixed effects are included but unreported. As proxy for financial market sophistication, in this Table we adopt the logarithm of the ratio of origin countries' equity market capitalisation-over-GDP; other variables are described in the 'Data' section.

\footnotetext{
${ }^{10}$ Note that, according to Davis et al. (2000) argument, origin countries financial sophistication should favour their FDI, once foreign countries' conditions prove as preferable to those of their home country. On the contrary, countries with less developed financial markets could face higher costs (barriers to entry) in investing abroad. This would bias them towards investing in their home market.
} 
Table 11

Estimation results on the impact of banking and sovereign risk on inward FDI in the EMU, controlling for origin countries' Business Cycle (BC). Regression results obtained by OLS.

\begin{tabular}{|c|c|c|}
\hline & \multicolumn{2}{|c|}{ Country Risk } \\
\hline & Banking Risk & Sovereign Risk \\
\hline & (1) & (2) \\
\hline & $\log (\mathrm{FDI})$ & $\log (\mathrm{FDI})$ \\
\hline log (NPL ratio_orig) & $-0.113 * * *(0.037)$ & \\
\hline log (NPL ratio_host) & $0.061(0.040)$ & \\
\hline $\log$ (Sovereign yields_orig) & & $-0.765 * * *(0.107)$ \\
\hline log (Sovereign yields_host) & & $-0.360 * * *(0.125)$ \\
\hline $\mathrm{BC}$ & $0.103(0.077)$ & $-0.012(0.134)$ \\
\hline avg (log(import)) & $0.428 * * *(0.020)$ & $0.484 * * *(0.032)$ \\
\hline comm_lang & $1.453 * * *(0.369)$ & $1.796 * * *(0.378)$ \\
\hline $\log ($ distance $)$ & $-0.446 * * *(0.091)$ & $-0.305 * * *(0.109)$ \\
\hline contig & $1.503 * * *(0.374)$ & $0.732 *(0.385)$ \\
\hline comrelig & $0.881 * * *(0.256)$ & $0.598 *(0.333)$ \\
\hline colony & $-0.118(0.474)$ & $0.186(0.521)$ \\
\hline com_leg_orig & $-0.405^{* *}(0.159)$ & $0.290(0.224)$ \\
\hline corr (GDP) & $0.254 * *(0.125)$ & $0.143(0.167)$ \\
\hline $\log (\mathrm{vol} F X)$ & $-0.804 * * *(0.067)$ & $-0.691 * * *(0.091)$ \\
\hline $\log$ (taxes) & $0.275(0.318)$ & $0.196(0.393)$ \\
\hline Constant & $6.166 * * *(1.350)$ & $6.377 * * *(1.579)$ \\
\hline $\mathrm{N}$ & 9,406 & 5,911 \\
\hline Time FE & Yes & Yes \\
\hline R-squared & 0.496 & 0.535 \\
\hline
\end{tabular}

Notes: $*, * *$, and $* * *$ imply statistical significance at the 10,5 , and 1 percent levels respectively. In the parentheses are reported robust standard errors clustered within country pairs. Yearly time fixed effects are included but unreported. Origin countries' BC has been computed as the cyclical component of these countries' GDP, obtained using a Hodrick-Prescott filtering process with smoothing factor of 100; other variables are described in the 'Data' section. 
Table 12

Estimation results on the impact of banking and sovereign risk on inward FDI from non-EA countries in the EMU (GIIPS and non-GIIPS countries) by OLS.

\begin{tabular}{|c|c|c|c|c|}
\hline \multicolumn{5}{|c|}{ Country Risk } \\
\hline & $\begin{array}{l}\text { Banking Risk } \\
\text { measure }\end{array}$ & $\begin{array}{c}\text { Sovereign } \\
\text { Risk } \\
\text { measure }\end{array}$ & $\begin{array}{l}\text { Banking Risk } \\
\text { measure }\end{array}$ & $\begin{array}{c}\text { Sovereign Risk } \\
\text { measure }\end{array}$ \\
\hline & \multicolumn{2}{|c|}{ non-GIIPS } & \multicolumn{2}{|c|}{ GIIPS } \\
\hline & (1) & (2) & (3) & (4) \\
\hline & $\log (\mathrm{FDI})$ & $\log (\mathrm{FDI})$ & $\log (\mathrm{FDI})$ & $\log (\mathrm{FDI})$ \\
\hline log (NPL ratio_orig) & $-0.201 * * *(0.063)$ & & $-0.207 * * *(0.078)$ & \\
\hline log (NPL ratio_host) & $0.086(0.054)$ & & $0.085(0.294)$ & \\
\hline $\begin{array}{l}\log \text { (Sovereign } \\
\text { yields_orig) }\end{array}$ & & $-1.471 * * *(0.172)$ & & $-1.302 * * *(0.206)$ \\
\hline $\begin{array}{l}\log \text { (Sovereign } \\
\text { yields_host) }\end{array}$ & & $-0.428 *(0.221)$ & & $-1.061 * * *(0.297)$ \\
\hline $\operatorname{avg}(\log ($ import $))$ & $0.400 * * *(0.051)$ & $0.521 * * *(0.068)$ & $0.460 * * *(0.100)$ & $0.465 * * *(0.117)$ \\
\hline comm_lang & $-0.244(0.808)$ & $0.223(1.355)$ & $1.968 * * *(0.687)$ & $2.083 * *(0.821)$ \\
\hline $\log ($ distance $)$ & $-0.806 * * *(0.134)$ & $-0.442 * * *(0.156)$ & $-0.593 * * *(0.207)$ & $-0.514 * *(0.208)$ \\
\hline contig & $2.816^{* * *}(0.564)$ & $2.260 * * *(0.627)$ & $-0.522(1.329)$ & $-1.733(1.074)$ \\
\hline comrelig & $0.036(0.444)$ & $-0.688(0.580)$ & $-0.006(0.453)$ & $0.044(0.646)$ \\
\hline colony & $1.180(0.736)$ & $0.817(0.888)$ & $1.605(1.071)$ & $3.167 * *(1.246)$ \\
\hline com_leg_orig & $-0.186(0.258)$ & $0.598 *(0.337)$ & $-0.700 * * *(0.249)$ & $-0.131(0.406)$ \\
\hline $\operatorname{corr}(\mathrm{GDP})$ & $0.096(0.188)$ & $0.411(0.273)$ & $0.179(0.243)$ & $-0.094(0.302)$ \\
\hline $\log (\operatorname{vol~FX)}$ & $-0.997 * * *(0.105)$ & $-0.806 * * *(0.143)$ & $-1.116 * * *(0.156)$ & $-1.013 * * *(0.176)$ \\
\hline $\log ($ taxes $)$ & $0.448(0.504)$ & $0.537(0.599)$ & $0.033(0.821)$ & $1.014(0.889)$ \\
\hline Constant & $9.810 * * *(2.088)$ & $8.634 * * *(2.320)$ & $9.138 * * *(3.220)$ & $8.823 * * *(3.284)$ \\
\hline $\mathrm{N}$ & 5,215 & 2,930 & 2,660 & 1,575 \\
\hline Time FE & Yes & Yes & Yes & Yes \\
\hline R-squared & 0.293 & 0.427 & 0.295 & 0.478 \\
\hline
\end{tabular}

Notes: *,**, and *** imply statistical significance at the 10,5, and 1 percent levels respectively. In the parentheses are reported robust standard errors clustered within country pairs. Yearly time fixed effects are included but unreported. See the 'Data' section for variable description. 
Table 13

Estimation results on the impact of banking and sovereign risk on inward FDI in the EMU, controlling for the size and capital intensity of origin and host countries. Regression results obtained by OLS.

\begin{tabular}{|c|c|c|}
\hline & \multicolumn{2}{|c|}{ Country Risk } \\
\hline & Banking Risk & Sovereign Risk \\
\hline & (1) & (2) \\
\hline & $\log (\mathrm{FDI})$ & $\log (\mathrm{FDI})$ \\
\hline log (NPL ratio_orig) & $-0.080 * *(0.040)$ & \\
\hline $\log$ (NPL ratio_host) & $-0.014(0.042)$ & \\
\hline $\log$ (Sovereign yields_orig) & & $-1.107 * * *(0.118)$ \\
\hline $\log$ (Sovereign yields_host) & & $-0.684 * * *(0.124)$ \\
\hline ln_sumGDPg & $-0.038(0.040)$ & $-0.147 * * *(0.049)$ \\
\hline L1_log (diffGDPpc) & $0.112 * * *(0.009)$ & $0.077 * * *(0.010)$ \\
\hline avg (log(import)) & $0.461 * * *(0.038)$ & $0.507 * * *(0.046)$ \\
\hline comm_lang & $1.438 * * *(0.407)$ & $1.560 * * *(0.442)$ \\
\hline $\log ($ distance $)$ & $-0.882 * * *(0.094)$ & $-0.579 * * *(0.112)$ \\
\hline contig & $2.052 * * *(0.387)$ & $1.353 * * *(0.401)$ \\
\hline comrelig & $1.224 * * *(0.275)$ & $0.847 * *(0.353)$ \\
\hline colony & $0.451(0.475)$ & $0.914 *(0.534)$ \\
\hline com_leg_orig & $-0.109(0.173)$ & $0.749 * * *(0.226)$ \\
\hline corr (GDP) & $0.128(0.132)$ & $-0.052(0.175)$ \\
\hline $\log (\mathrm{vol} \mathrm{FX})$ & $-0.808 * * *(0.082)$ & $-0.740 * * *(0.101)$ \\
\hline $\log (\operatorname{taxes})$ & $0.384(0.344)$ & $0.467(0.410)$ \\
\hline Constant & $9.788 * * *(1.430)$ & $9.410 * * *(1.573)$ \\
\hline $\mathrm{N}$ & 9,626 & 6,088 \\
\hline Time FE & Yes & Yes \\
\hline R-squared & 0.432 & 0.499 \\
\hline
\end{tabular}

Notes: $*, * *$, and $* * *$ imply statistical significance at the 10,5 , and 1 percent levels respectively. In the parentheses are reported robust standard errors clustered within country pairs. Yearly time fixed effects are included but unreported. In this Table, we use the natural logarithm of the sum of GDP growth of origin and host country as proxy for size of the economies involved in the bilateral transaction. We exploit the first lag of the natural logarithm of the difference in origin and host countries GDP per capita to control instead for the economies' capital intensity. 